\title{
A second look at the poetics of re-enactment in Ode 13 of Bacchylides
}

\section{Citation}

Nagy, Gregory. 2011. A Second Look at the Poetics of Re-enactment in Ode 13 of Bacchylides. In Archaic and Classical Choral Song: Performance, Politics and Dissemination, eds. by L. Athanassaki and E. L. Bowie, 173-206. Berlin: De Gruyter.

\section{Published Version}

doi:10.1515/9783110254020.173

\section{Permanent link}

http://nrs.harvard.edu/urn-3:HUL.InstRepos:15550091

\section{Terms of Use}

This article was downloaded from Harvard University's DASH repository, and is made available under the terms and conditions applicable to Other Posted Material, as set forth at http:// nrs.harvard.edu/urn-3:HUL.InstRepos:dash.current.terms-of-use\#LAA

\section{Share Your Story}

The Harvard community has made this article openly available.

Please share how this access benefits you. Submit a story.

\section{Accessibility}




\section{A second look at the poetics of re-enactment in Ode 13 of Bacchylides}

\section{Gregory Nagy}

[[Originally printed 2011 in Archaic and Classical Choral Song: Performance, Politics and Dissemination (ed. L. Athanassaki and E. L. Bowie) 173-206. Berlin. The page-numbers of the printed version are embedded within brackets in this electronic version: for example, $\{173 \mid 174\}$ marks where p. 173 stops and p. 174 begins.] $]^{1}$

\section{Introduction}

Ode 13 of Bacchylides celebrated the victory of Pytheas of Aegina in the athletic contests held at Nemea. The same victory of Pytheas in the Nemean contests was celebrated in another ode, this one composed by the rival poet Pindar, which we know as Nemean $5 .{ }^{2}$ Pytheas competed in the athletic event known as the pankration, and the date of his victory is probably $485 \mathrm{BCE} .{ }^{3}$ Ode 13 of Bacchylides glorified not only Pytheas as honorand but also his father, Lampon, and an Athenian "trainer" by the name of Menandros. ${ }^{4}$ In addition, Ode 13 glorified the patriliny of Pytheas, that is, the Psalykhiadai of Aegina, as well as the heroic lineage of the Aiakidai, from which lineage the patriliny of the Psalykhiadai and other patrilinies in Aegina were notionally derived. ${ }^{5}$

In my article here, I offer a new analysis of such a notional derivation, concentrating on what Ode 13 of Bacchylides has to say about the heroic lineage of the Aiakidai and about the

\footnotetext{
${ }^{1}$ The original version of this article was a paper presented at the conference "Space and time in choral poetry," held at Corpus Christi College (Oxford) in June 2008.

${ }^{2}$ Also relevant are two other victory odes by Pindar, Isthmian 5 and 6 , which both glorified the victories of the younger brother of Pytheas, Phylakidas, in the athletic contests held at the Isthmus of Corinth.

${ }^{3}$ Fearn 2007:87,

${ }^{4}$ On Menandros: Fearn 2007:152-160.

${ }^{5}$ On such "notional" derivations of patrilinies from the heroic lineage of the Aiakidai, see Nagy 1990a:175-176, 178-179 (6§§56, 60); also Fearn 2007:143.
} 
relationship of this lineage to the island state of Aegina, named after a nymph by the same name who was fathered, according to Aeginetan myth, by the river god Asopos. ${ }^{6}\{173 \mid 174\}$

The relationship of the Aiakidai to Aegina is expressed in Ode 13 of Bacchylides by the group of young men who perform the ode, both singing it and dancing it. The word used to express the combined singing and dancing is melpein (line 190). By way of their singing and dancing, as I will argue, they are re-enacting the Aiakidai themselves. Such re-enactment, as I will also argue, is understood as an act of mimēsis.

But there is more to it. The group of young men is not only re-enacting the Aiakidai. It is also re-enacting an embedded group of parthenoi 'maidens' (line 94) who notionally sing and dance the myth of the Aiakidai. Again, the word used to express the combined singing and dancing is melpein (line 94). And, in this case as well, I will argue that such re-enactment is an act of mimēsis.

I say that the singing and dancing of the maidens is embedded in the ode because these maidens are quoted, as it were, by the group of young men who are said to be singing and dancing the ode. And I say that the maidens notionally sing and dance the story of the Aiakidai because this story is actually being performed by the group of young men who are re-enacting a song and dance performed by the group of maidens.

The embedding of the performance of this group of maidens within the performance of a group of young men in Ode 13 of Bacchylides has been studied by Timothy Power in an article he published in 2000. ${ }^{7}$ This article of Power on Ode 13 is for me an essential point of reference in my own study of this ode. That is why I gave this article the title "A second look at Ode 13 of Bacchylides."

\footnotetext{
${ }^{6}$ A note on usage: I will regularly latinize "Aeginetan" and "Aegina."

${ }^{7}$ Power 2000.
} 
Another reason for my thinking of my study as a "second look" has to do with an article published in 2007 by Claude Calame. ${ }^{8}$ In that important article, Calame makes arguments that converge with the argumentation in Power's earlier 2000 article, which Calame had not yet seen when he wrote his 2007 article. In a second version of that article, however, published in 2009, Calame has taken a second look at his own argumentation, citing the arguments of Power. ${ }^{9}$ And, in that same article, Calame also cites the relevant arguments I presented in a 2008 conference paper that supported both his arguments and the arguments of Power. ${ }^{10}$ Taking my own second look at all these arguments combined, I highlight a central point of agreement: the represented singing and $\{174 \mid 175\}$ dancing of the story of the Aiakidai by the maidens in Ode 13 of Bacchylides is a way of linking the mythical past with the ritual present.

Still another reason for my thinking of my article here as a "second look" at Ode 13 of Bacchylides has to do with a book published in 2007 by David Fearn on the odes of Bacchylides. ${ }^{11}$ The commentary of Fearn on Ode 13, in which he engages with the article of Power, is for me an important point of reference in my own study of this ode.

In analyzing the story of the Aiakidai as sung and danced in Ode 13 of Bacchylides, I draw on some of my own previous argumentation as developed in an earlier article that is part of a collection of articles edited by David Fearn dealing with the Aeginetan odes of Pindar. ${ }^{12}$ In that earlier article, "Asopos and his multiple daughters," I argue that the identity of the nymph Aegina as the daughter of the river god Asopos is linked with her identity as the mother of all

\footnotetext{
${ }^{8}$ Calame 2007, especially pp. 185-191.

${ }^{9}$ Calame 2009, especially p. 9 n15.

${ }^{10}$ Calame 2009, especially p. $10 \mathrm{n} 16$, with reference to my conference paper as mentioned here at $\mathrm{n} 1$ above.

${ }^{11}$ Fearn 2007.

${ }^{12}$ Fearn 2011.
} 
the Aiakidai, which in turn is linked with her identity as the Mother Earth of all the Aeginetans. ${ }^{13}$

In what follows, the argument in "Asopos and his multiple daughters" is taken further. I will now make the further argument that the nymph Aegina and her female attendants are actually being re-enacted in Ode 13. That is, they are being re-enacted in the act of singing and dancing in a chorus, and the re-enactors are the group of young men who are said to be singing and dancing the song that is Ode 13 of Bacchylides. Even further, I will argue that this same group of young men is also re-enacting the Aiakidai of the heroic age.

I start by giving a preview of the text of Ode 13, highlighting those words that are most relevant, followed by a selective translation and commentary.

\section{A compressed preview of the text of Ode 13 of Bacchylides, based on the edition of Maehler 1982}

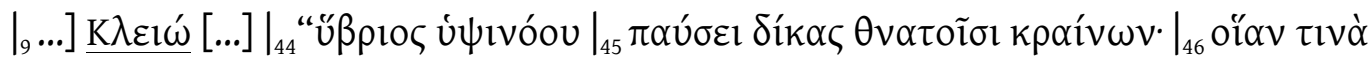

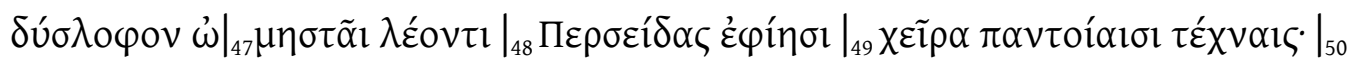

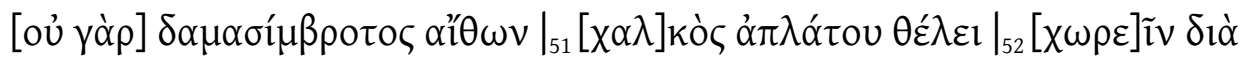

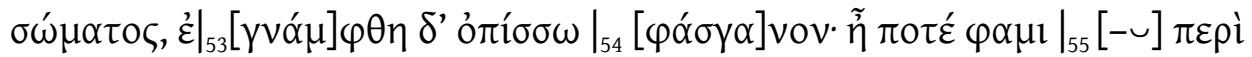

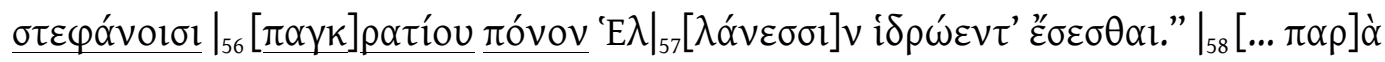

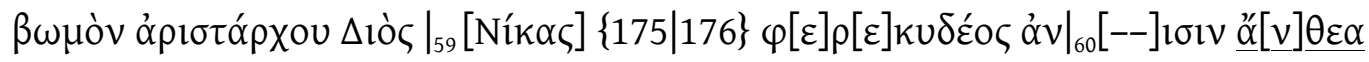

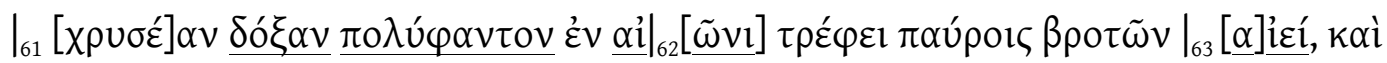

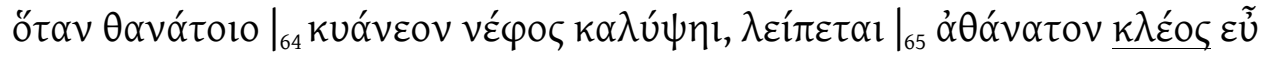

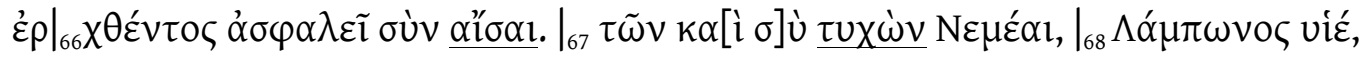

\footnotetext{
${ }^{13}$ Nagy 2010.
} 


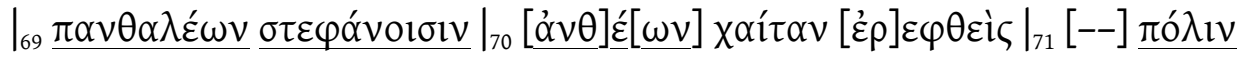

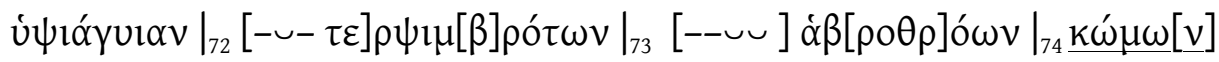

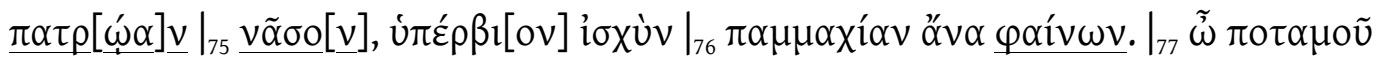

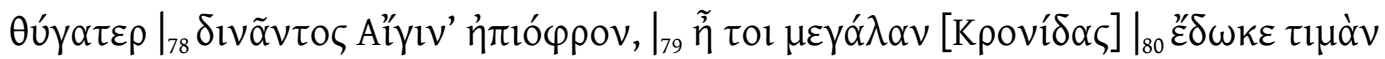

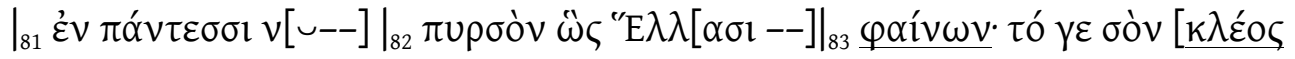

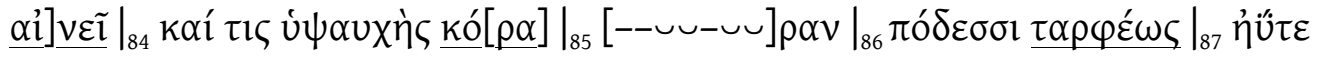

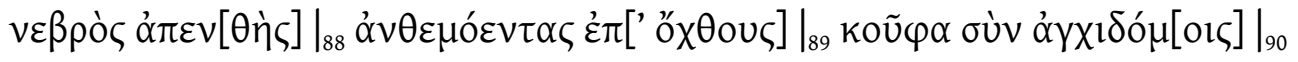

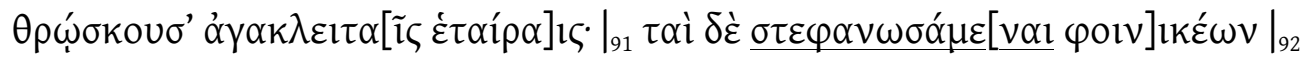

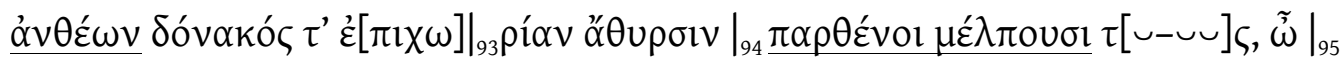

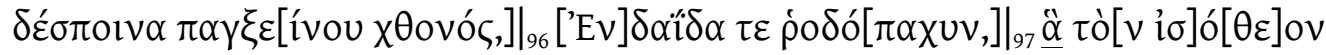

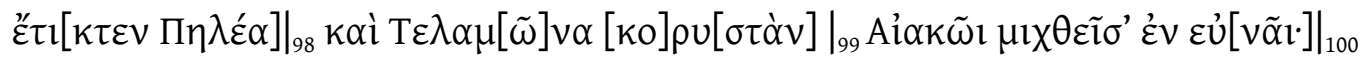

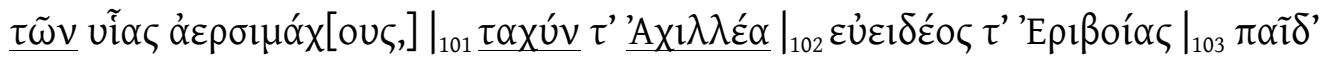

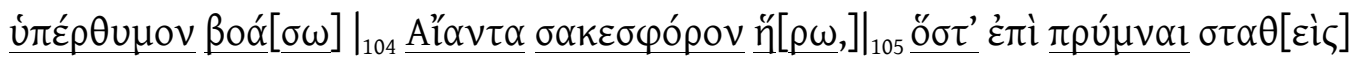

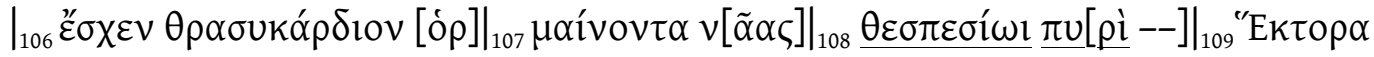

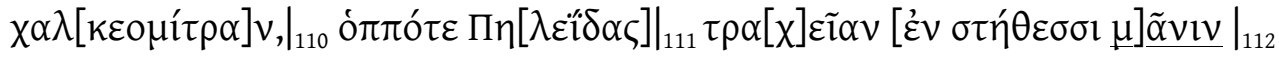

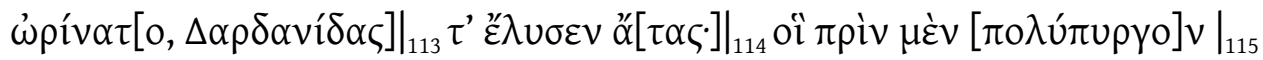

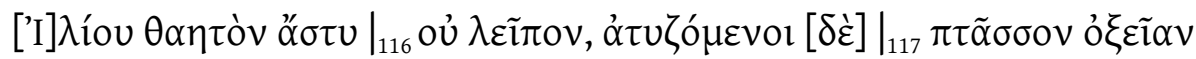

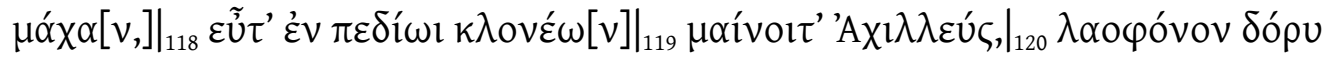

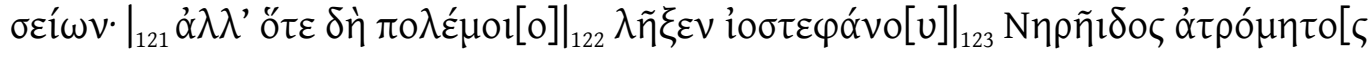

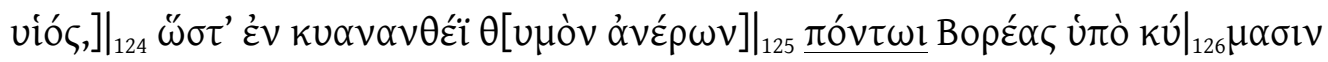

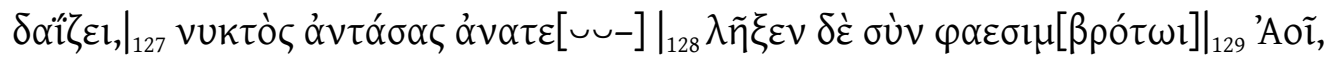

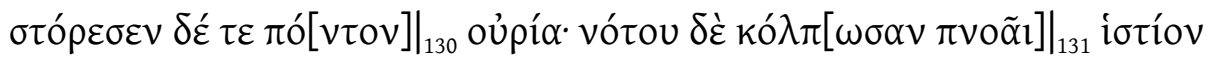

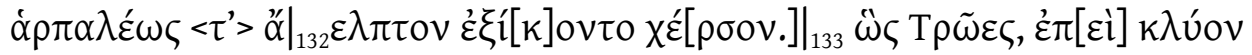

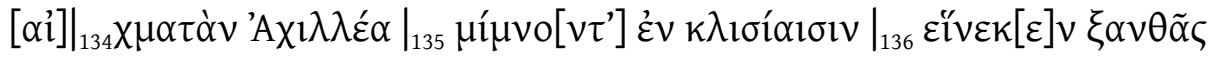




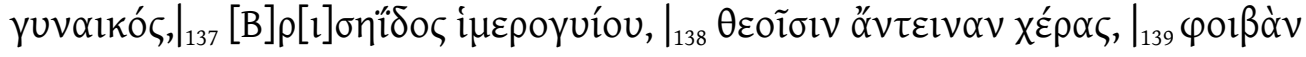

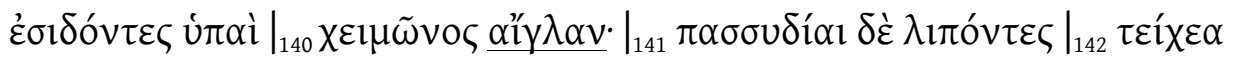

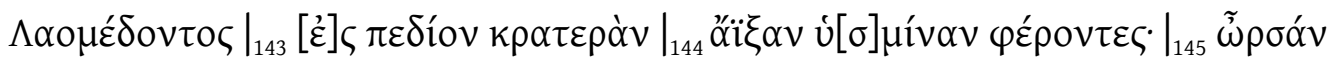

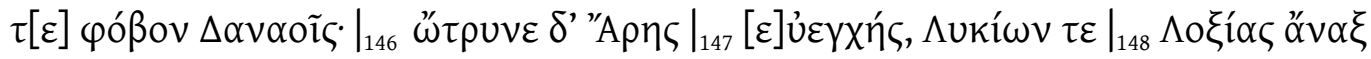

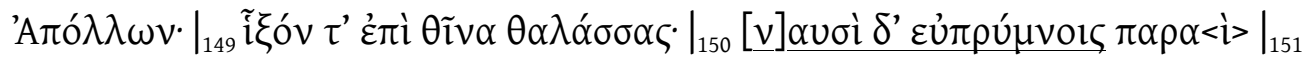

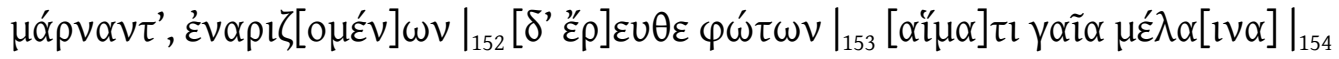

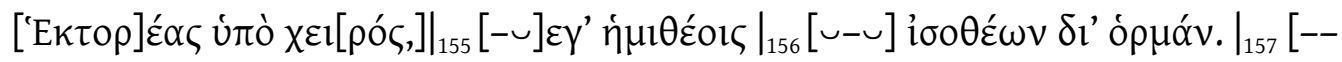

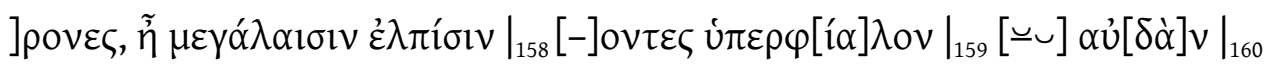

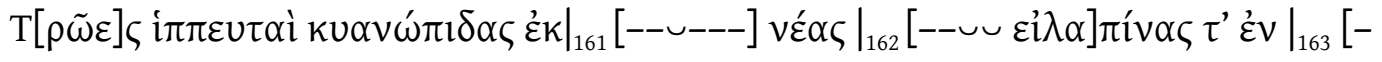

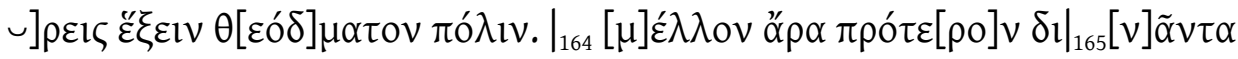

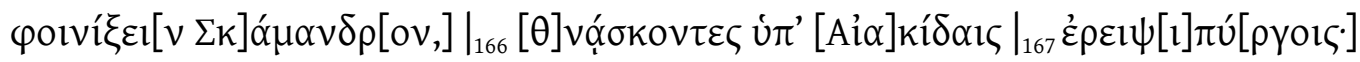

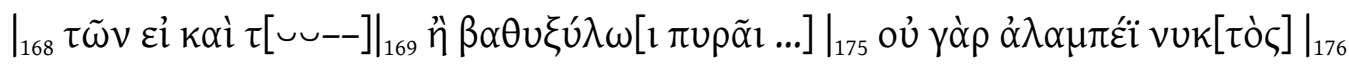

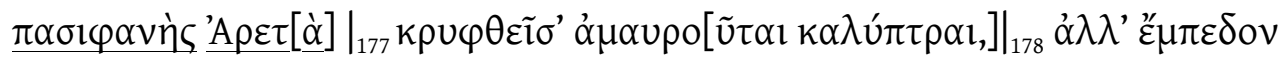

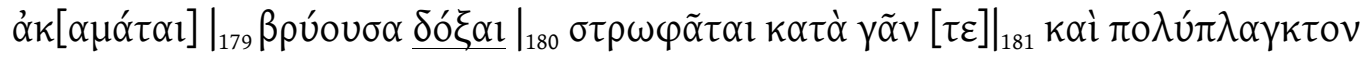

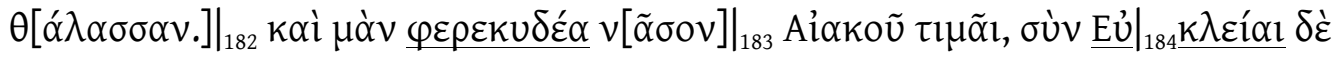

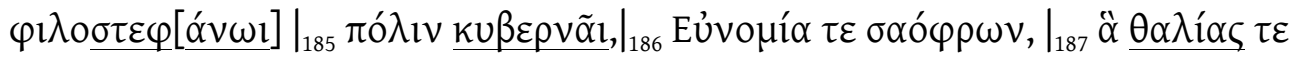

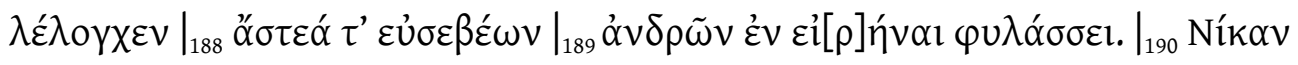

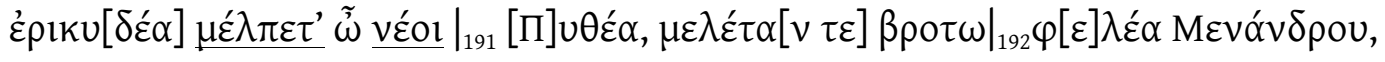

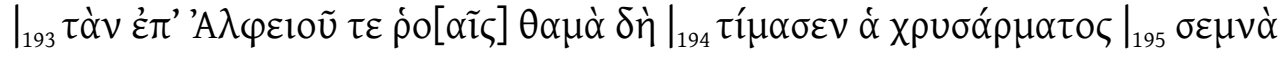

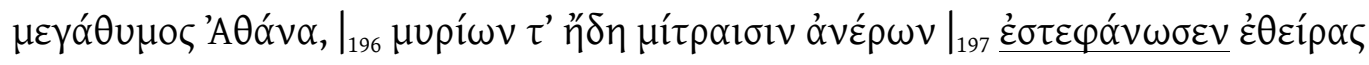

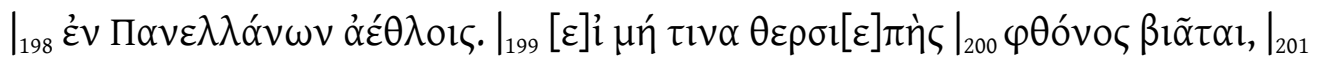

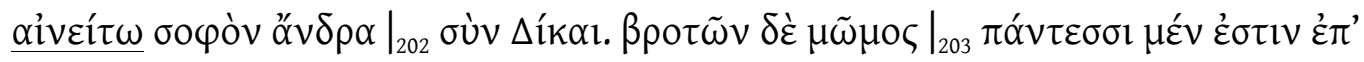

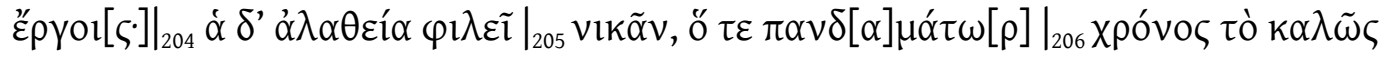

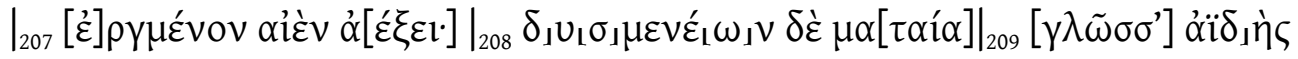




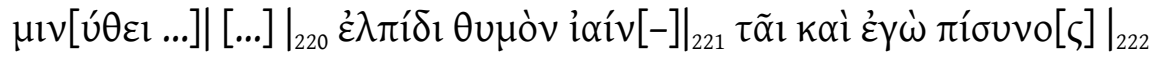

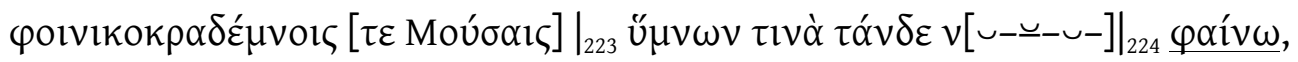

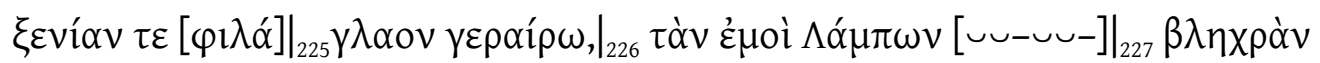

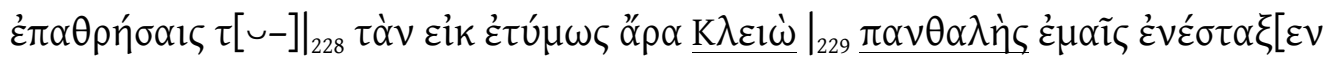

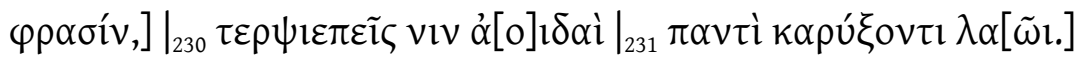

\section{About the formatting of this previewed text}

The vertical sign with a lower-case number to the right (for example, "| $\left.\right|_{44}$ ") indicates the number of the following line, in this case, line 44).

The ellipsis sign (that is, “...") indicates a gap in the text. Some of the gaps are enormous, as at the very beginning of the quoted text, where the gap extends from line 9 to line 44 .

The bold text indicates Greek words that are highlighted. An example is $\underline{K \lambda \varepsilon 1 \omega}$ at line 9. Such highlighted wording will be transliterated in the commentary that follows. So, I will transliterate Kleiō at line 9. Such transliterated Greek wording will also be translated in the commentary. An example is $k \lambda \varepsilon^{\prime}$ oৎ at line 65 , which will be transliterated as kleos and translated as 'glory'. $\{177 \mid 178\}$

\section{Selective translation and commentary}

$\mid, \ldots] \underline{K \lambda \varepsilon 1 \omega ́}$

Kleiō

Bacchylides Ode 13 line 9

Kleiō is the Muse who presides over the kleos 'glory' of song or poetry, as represented by the lyric medium of Bacchylides as also by the epic medium of Homeric poetry. The name of Kleiō 
recurs at the end of the song, at line 228 , in a most significant context that will be analyzed in due course.

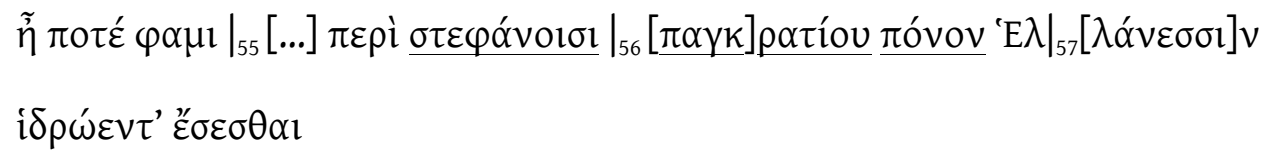

'Truly I say that there will be for all Hellenes, sometime in the future, the ordeal [ponos] of the pankration, marked by much sweating in competition for garlands [stephanoi].'

In the wording of this quoted prophecy, the athletic event of the pankration, which is a prominent feature of the athletic festival of the Nemea, is being foretold. The victory of the hero Herakles over the Nemean lion is an aetiology that is linked here with the event of the pankration at the athletic festival of Nemea. (By aetiology, I mean a myth that motivates an institutional reality, especially a ritual. ${ }^{14}$ ) The winner of the pankration who is being celebrated here in Ode 13 is linked with the winner of the primal pankration of Nemea, which is the struggle of Herakles with the Nemean lion. ${ }^{15}$ That primal struggle is a mythical 'ordeal' or ponos, which corresponds to the ritual ponos 'ordeal' as experienced by the athletes who competed in the pankration at the festival of Nemea. ${ }^{16}$

$\left.\right|_{55}[. ..] \pi \varepsilon \rho \grave{~} \underline{\sigma \varepsilon \varphi \varphi \alpha ́ v o l \sigma l}$

'in competition for garlands [stephanoi]'

\footnotetext{
${ }^{14}$ Nagy 1979:279 (16\$2n2).

${ }^{15}$ On the aetiological significance of the struggle of Herakles with the Nemean lion, see Fearn 2007:148-149.

${ }^{16}$ On the use of ponos 'ordeal' and related words in the victory ode, see Nagy 1990a ch.5.
} 
The mention of stephanoi 'garlands' here links the mythical victory of Herakles with the ritual victory of the athlete who won the competition. A stephanos or 'garland' is a circle or 'crown' (as in Latin corona) of plaited blossoms to be placed on the victor's head of hair. $\{178 \mid 179\}$

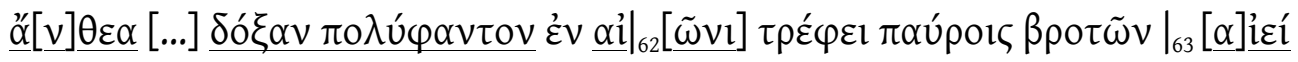 \\ '[...] the blossoms [anthea] nurture a fame [doxa] that is polu-phantos (made \\ visible [phainein] to many) in the recircling of time [aiōn] - a fame meant for only \\ a few mortals, lasting forever [aiei].'
}

Bacchylides Ode 13 lines 61-63

The ritual tradition of making a garland by linking blossoms together into a circle is relevant to the linking that we see here between the adverb aiei 'forever' and the noun aion in the sense of a 'recircling of time'. In fact, the adverb aiei 'forever' is the old locative singular of this noun aiōn, and this locative means literally 'in a recircling of time', signaling an eternal return. ${ }^{17}$ As for the anthea 'blossoms' at line 60 here, they are identical with the blossoms that are linked together into the garland mentioned earlier at line 55. As for the doxa 'fame' at line 60 , which is 'nurtured' by the blossoms of this garland, it is identical with the kleos 'glory' of song or poetry, as mentioned in the passage that immediately follows this one.

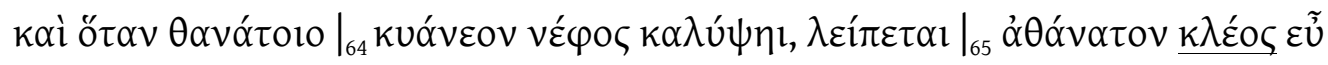
$\left.\dot{\varepsilon} \rho\right|_{6 \sigma} X \theta \varepsilon \dot{v} v \tau \circ \varsigma \alpha \grave{\alpha} \sigma \varphi \alpha \lambda \varepsilon \tilde{\varepsilon} \sigma o ̀ v \underline{\alpha i ́ \sigma \alpha l}$

\footnotetext{
${ }^{17}$ Nagy 1990a:195n210 (6§88).
} 
'And when the dark blue cloud of death covers over these few (victors), what gets left behind $\left.\right|_{65}$ is an undying ${ }_{65}$ glory $[k l e o s]$ for what they did so well, in accord with a ${ }_{66}$ destiny [aisa] that cannot be dislodged.'

Bacchylides Ode 13 lines 63-66

Just as the blossoms of the garland mentioned earlier at line 55 nurture the eternal doxa 'fame' of those few mortals whose athletic victories are celebrated at festivals, so also they nurture the eternal kleos 'glory' of those mortals - a glory conferred by song or poetry. The medium of song or poetry is its own message, which is glory. This glory is compared to a garland, a circle of blossoms all linked together, and this circle is eternal.

There is a parallel theme in epic. In compensation for his being cut down in the bloom of his youth, Achilles is destined to have a kleos 'glory' that is aphthiton 'unwilting': that is what the hero's mother foretells for him, as Achilles himself is quoted as saying (Iliad IX 413). In epic as well as in lyric, kleos expresses not only the idea of prestige as conveyed by the translation 'glory' but also the idea $\{179 \mid 180\}$ of a medium that confers this prestige. ${ }^{18}$ In the victory odes, the poet can proudly proclaim his mastery of the prestige conferred by kleos (as in Pindar Nemean 7.61-63).$^{19}$ As for the word aphthiton 'unwilting', it is used as an epithet of kleos not only in epic but also in lyric, as we see from the songs of Sappho (F 44.4) and Ibycus (F 282.47). This epithet expresses the idea that the medium of kleos is a metaphorical flower that will never stop blossoming. As the words of a song by Pindar predict, the hero who is glorified by the kleos will die and will thus stop blossoming, that is, he will 'wilt', phthinein, but the medium that conveys the message of death will never wilt: that medium is pictured as a choral lyric song eternally sung by the Muses as they lament the beautiful wilted flower that is Achilles, the

\footnotetext{
${ }^{18}$ Nagy 1979:15-18 (1§§2-4).

${ }^{19}$ Nagy 1990a:147 (6\$3).
} 
quintessential beau mort (Isthmian 8.56a-62).$^{20}$ I will explain in due course what I mean here by the term choral lyric. The term applies also to the song that is sung by Thetis accompanied by her fellow Nereids as they lament in the Iliad the future death of her beloved son: here again, Achilles is figured as a beautiful flower cut down in full bloom (XVIII 54-60). ${ }^{21}$ In the Odyssey, we find a retrospective description of the lament sung by Thetis and her fellow Nereids at the actual funeral of Achilles, followed by the lament of the Muses themselves (xxiv 58-59, 60-62). ${ }^{22}$

Of those few mortals who partake of such glory, the one who is primarily being glorified by the song of Ode 13 is the son of Lampon, Pytheas, victor at the athletic event of the pankration in Nemea, as we will see in the passage that immediately follows. As we will also see in this next passage, the victor's head of hair is crowned with the blossoms of garlands.

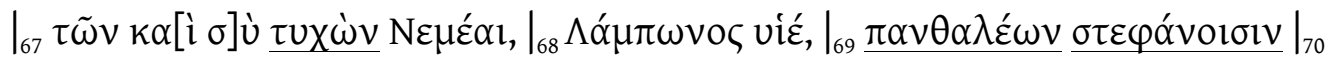
$[\alpha \dot{\alpha} v \theta] \underline{\varepsilon}[\omega \nu] \chi \alpha \hat{i} \tau \alpha \nu[\dot{\varepsilon} \rho] \varepsilon \varphi \theta \varepsilon i \varsigma$

'These things are what you have ${ }_{67}$ won [tunkhanein] at Nemea (just as those previous few mortals have won them), O son of Lampon, you with your head of hair encircled by ${ }_{69}$ garlands [stephanoi] of 70 blossoms [anthea] ${ }_{69}$ all abloom [panthalea].'

Bacchylides Ode 13 lines 67-70

$\{180 \mid 181\}$ What are 'these things', these figurative prizes won by the victorious athlete? From the evidence of other victory odes, we can see that there are two such prizes:

\footnotetext{
${ }^{20}$ Nagy 2007b:36; also Nagy 1990a:204-206 (7§6).

${ }^{21}$ Nagy 1979:182-183 (10\$11).

${ }^{22}$ Nagy 2007b:36.
} 
1. 1) A primary prize for the athlete to win, as expressed by the verb tunkhanein, must be the song that is the victory ode itself. An example is the wording in Pindar

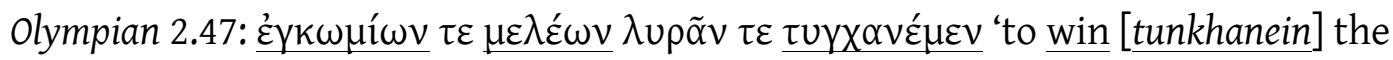
melodies [melea] of enkōmia (songs sung in victory revels [kōmoi] and of lyres' (we may compare also Pythian 8.38)..$^{23}$ In the case of Ode 13 of Bacchylides, as we have seen, the doxa or 'fame' of the victorious athlete is expressed by the kleos or 'glory' of the song that is Ode 13.

2. 2) A secondary prize for the athlete to win, again as expressed by the verb tunkhanein, must be the garlands or stephanoi that signal the festive occasion of victory.

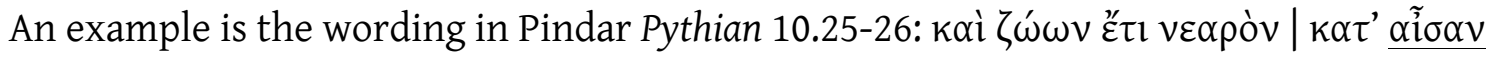

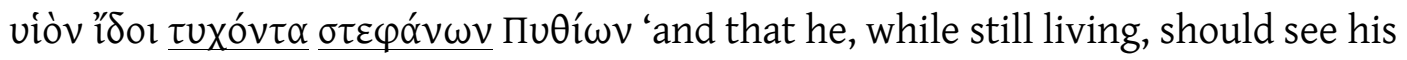
young son, in accord with destiny [aisa], win [tunkhanein] the garlands [stephanoi] of the Pythian festival'. The wording here is closely parallel to what we have already seen in

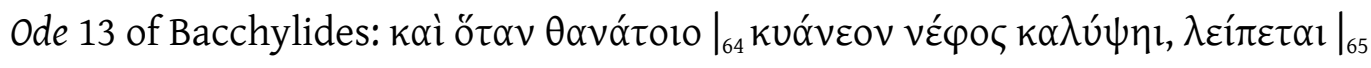

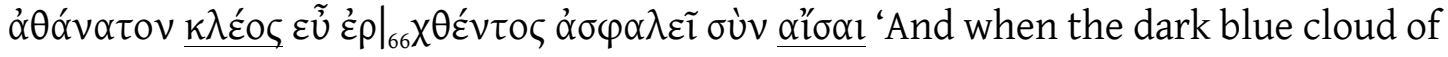
death covers over these few (victors), what gets left behind is an undying glory [kleos] for what they did so well, in accord with a destiny [aisa] that cannot be dislodged.' So aisa 'destiny' guards against the danger of reversals in fortune from one generation to the next.

The wording of Ode 13 provides further evidence. In what follows, we will see additional references to the two figurative prizes that I have just highlighted, which are:

3. 1) the song that is Ode 13 , which is equated with doxa 'fame' and kleos 'glory'

\footnotetext{
${ }^{23}$ Commentary in Nagy 1990a:194 (6\$87).
} 
4. 2) the stephanoi or 'garlands' mentioned in the song, which are likewise equated with the song.

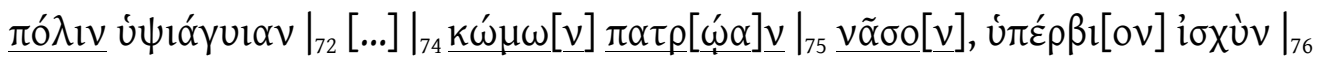

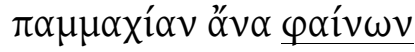

'([...] You come to your ${ }_{71}$ city [polis] with its lofty causeways, to the ${ }_{75}$ island $[\underline{\text { nessos}}]_{74}$ of your ancestors [patrōia], in a setting of ${ }_{74}$ revels $[$ kōmoi $],{ }_{76}$ making visible [phainein] the overwhelming power it takes to engage in the contests of the pankration.'

Bacchylides Ode 13 lines 71-76

How is the charismatic power of the victorious athlete 'made visible' to the world? The word phainein at line 76, meaning 'make visible', is being $\{181 \mid 182\}$ linked here to the power of the song to visualize its own power to visualize. The same word phainein 'make visible' is used in a comparable sense at line 83, in a passage we will consider in due course.

$$
\begin{aligned}
& \kappa \omega ́ \mu \omega[v] \\
& \text { kōmoi 'revels' }
\end{aligned}
$$

The power to visualize the power to visualize is derived from the epichoric (that is, local) setting of the song. And the word for that epichoric setting is kōmos, as we see it used here.

The noun kömos, which means 'revel' or 'group of revelers', is the word for both the occasion and the medium of performing songs that we know as victory odes. In the traditional 
language of the victory ode, as we see it attested in the songs of Pindar and Bacchylides, kōmos is the conventional word for referring to a group of young men who sing and dance the ode, while the word khoros, even though it actually means 'group of singers and dancers', is never directly used in the victory odes with reference to such a group of young men ${ }^{24}$ In any case, when I say choral lyric in this presentation, I have in mind any medium of singing and dancing by a group, whether this group is a kömos or a khoros.

The plural use of kōmos here at line 74 indicates that the singing and dancing of the komos is understood as a form of celebration that recurs at each new occasion of celebrating a victory. Such a recurring form of celebration is understood here as a custom that is native to the island-state of Aegina - a custom handed down to the Aeginetans from their ancestors. And, in this context, the island is described pointedly as patrōia 'ancestral' at line 74 .

Not only in Ode 13 here but also in all the victory odes of Pindar and Bacchylides, the kōmos is understood as the basic traditional medium for a festive celebration of victory. ${ }^{25}$ And such an understanding of the kōmos is built into the meaning of the noun enkōmion, 'encomium', which refers to the occasion of such festive celebration. ${ }^{26}$ Relevant is the formulation of Elroy Bundy: "there is no passage in Pindar and Bacchylides that is not in its primary intent encomiastic that is, designed to enhance the glory of a particular patron." ${ }^{27}$ In this context I must express $\{182 \mid 183\}$ my disagreement with those who think that the victory ode, as a genre, is "new." 28 Even if the victory ode, unlike other related genres of singing and dancing in groups, is not necessarily tied to seasonally recurring festivals, it does not follow that this particular genre is

\footnotetext{
${ }^{24}$ Power 2000:68; also p. 77, with reference to Bundy 1986:2 and Nagy 1994/1995:22.

${ }^{25}$ Nagy 1979:227 (12§7), 1990a:142 (5\$12), 390 (13\$18n43).

${ }^{26}$ Nagy 1979:253-255, 260 (14§§2-4, 11).

${ }^{27}$ Bundy 1986:3. In quoting this formulation, I have taken the liberty of latinizing Bundy's spelling of words derived from Greek.

${ }^{28}$ For a helpful survey of works that follow this line of thinking, see Power 2000:76-78.
} 
therefore somehow out of tune with established traditions of festive songmaking. For me the very fact that the victory ode calls its own occasion a kōmos is a clear indication that this genre is a very old and traditional form of ad hoc celebration. ${ }^{29} \mathrm{I}$ hold that the only thing really "new" about the genre of the victory ode as we see it attested in the songs of Pindar and Bacchylides is the newness of the historical realities that kept reshaping this genre in the early fifth century BCE.

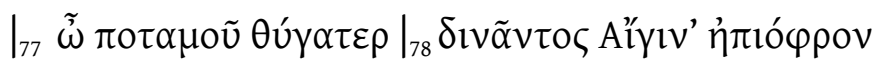

O daughter of the swirling stream (of Asopos), Aegina, you with the caring heart.

Bacchylides Ode 13 lines 77-78

The nymph Aegina, daughter of the river Asopos, is invoked here. In the article "Asopos and his multiple daughters," as I have already indicated, I argue that the identity of the nymph Aegina as the daughter of the river god Asopos is linked with her identity as the mother of all the Aiakidai, which in turn is linked with her identity as the Mother Earth of all the Aeginetans. ${ }^{30}$

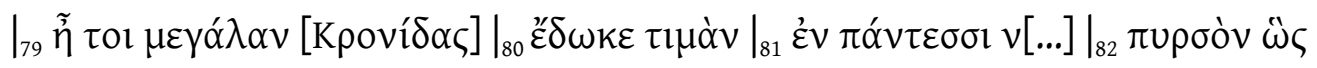
"E $\left.\lambda \lambda[\alpha \sigma l--]\right|_{83} \varphi \alpha i ́ v \omega v$

'Truly has [Zeus the son of Kronos] given honor to you (Aegina), making it visible [phainein] like a beacon light for all Hellenes.'

Bacchylides Ode 13 lines 79-83

\footnotetext{
${ }^{29}$ For more on the kōmos as an old tradition of songmaking, see Nagy 2007a.

${ }^{30}$ Nagy 2010.
} 
The honor that Zeus gives to Aegina as the Mother Earth of the Aeginetans is made visible by him through the medium of the song that is Ode 13 . The word phainein at line 83 , meaning 'make visible', is being used here in a way that is comparable to the way it is used in an earlier passage, at line 76. As we saw there, this word phainein 'make visible' is linked to the power of the song to visualize its own power to visualize. But now we see something more from the use of this same word at line 83: the $\{183 \mid 184\}$ power of the song to visualize is a power that emanates from Zeus himself.

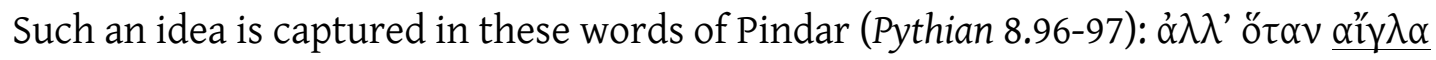

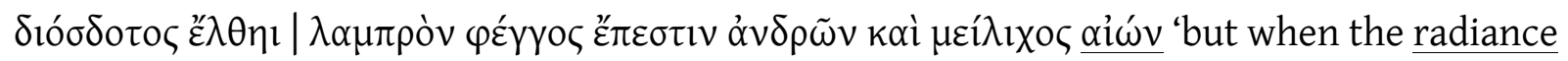
[aiglē] that is given by Zeus comes, then there is a light shining over men, and the recircling of time [aiōn] is sweet to the taste'. The light of illumination that emanates from Zeus is imagined here as the power of song to visualize it. ${ }^{31}$ And, as I will show later, the light that comes from Zeus in such a context is envisioned as a clear sky that follows a spell of fearsome darkness for sailors beset by a storm at sea.

Similarly in the words of Ode 13 of Bacchylides, the blossoms of the garland that is the song are said to illuminate the fame that the song confers on the victor (lines 61-63): $\underline{\alpha}[v] \theta \underline{\theta \varepsilon \alpha}[. .$.

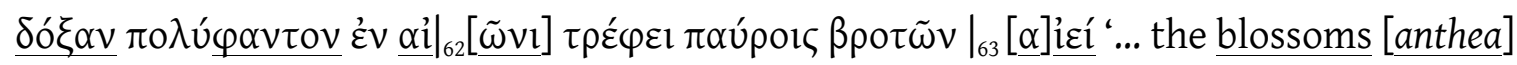
nurture a fame [doxa] that is polu-phantos (made visible [phainein] to many) in the recircling of time [aiōn] - a fame meant for only a few mortals, lasting forever [aiei]'.

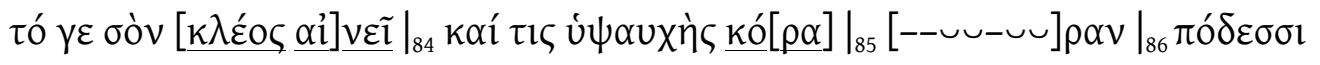

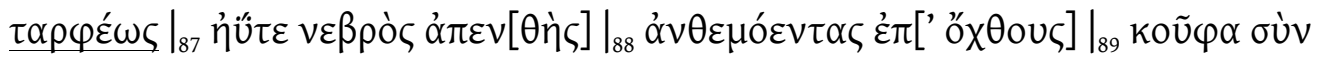

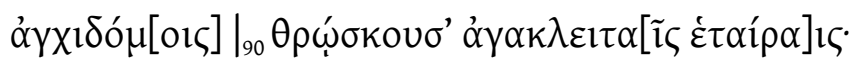

\footnotetext{
${ }^{31}$ Commentary in Nagy 2000.
} 
'As for your own [glory (kleos)] (O Aegina), also praising [aineîn] it is a maiden [korē] whose voice is sublime, with her dance steps, over and over again [tarpheōs], like a carefree fawn springing lightly over the hillsides full of blossoms [anthea], along with her companions who have their abodes nearby, and who have great glory [kleos].'

Bacchylides Ode 13 lines 83-90

The commentary on this difficult passage will be broken up into three parts, each headed by the relevant wording.

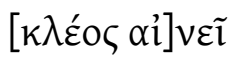

$$
\begin{aligned}
& \text { kleos 'glory' ... aineîn 'praise' }
\end{aligned}
$$

Bacchylides Ode 13 line 83

Traditionally, ainein 'praise' refers to the medium of the victory ode, the primary function of which is to praise whatever or whoever must be praised. As for the restored word kleos 'glory', if this restoration is correct, it would refer to the message of the victory ode, which focuses on the glorification of Aegina by way of praise. Alternatively, some would restore the

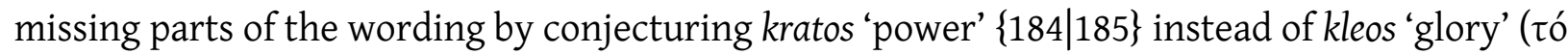

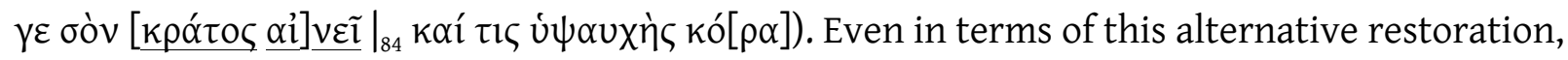
the point still remains that the word ainein 'praise' refers to the medium of the victory ode.

But there is more to it. The song of the victory ode has the power to authorize whatever or whomever the song highlights for praise, and this power to authorize by way of praise is conventionally expressed by way of the same word that I have so far translated simply as 
praise, ainein (a shining example is the passage in Pindar Nemean 7.61-63). ${ }^{32}$ In Ode 13 of Bacchylides, the song comes to an end with an injunction to authorize by way of praise, aineîn, the one who understands the song (201). I will quote and translate later the passage containing that injunction.

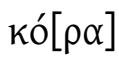

$$
\begin{aligned}
& \text { 'maiden' }
\end{aligned}
$$

The kore 'maiden' here is visualized as the lead singer and dancer of a khoros 'song and dance group' consisting of other maidens. The choral lyric performance of the khoros consisting of maidens is embedded within the choral lyric performance of a kōmos consisting of young men. ${ }^{33}$ The kore 'maiden' as the lead singer and dancer of the khoros is comparable to the prima donna of an opera or to the prima ballerina of a ballet. She is pictured here as a timeless ideal. As Power notes, she "is not necessarily confined to one specific identity or place in time (although in any one year she would be), but can perhaps best be thought of as a 'choral character' in the sense Nagy has used the term to identify Hagesikhora and Agido in Alcman [Song] 1: a role to be played each and every year on ritual occasions by a different daughter of the aristocracy." ${ }^{34}$ In this formulation of Power, he is referring to my overall argument about the khoros as a medium that makes mimesis: that is, the khoros is a medium that re-enacts in ritual song and dance what happens in myth..$^{35}$

\footnotetext{
${ }^{32}$ Commentary in Nagy 1979:223 (12\$3), 1990a:147-148 (6§3).

${ }^{33}$ Power 2000:71-74, 78-79.

${ }^{34}$ Power 2000:81, with reference to Nagy 1990a:346-348 (12\$§20-22) and Nagy 1994/1995:17

${ }^{35}$ Power 2000:70n10, with reference to Nagy 1996. In that book (pp. 56-57), I focus on two examples of choral performance: Song 1 of Alcman and the passage about the Delian Maidens in the Homeric Hymn to Apollo (verses
} 
In Ode 13 of Bacchylides, the mimessis visualizes what happens in myth, but it also visualizes what happens in the ritual that visualizes the $\{185 \mid 186\}$ myth. First, at line 84 , the leader of the khoros of maidens is visualized as she sings: she is 'a maiden [korē] whose voice is sublime'. Next, at lines 86 and following, she is visualized as she dances like a fawn, and she is attended by a whole khoros consisting of maidens who are her companions in the group (86-90).

$\tau \alpha \rho \varphi \varepsilon ́ \omega \varsigma$

'over and over again'

Bacchylides Ode 13 line 86

This word indicates, as Power argues, that the choral singing and dancing of the maidens and of their leader is envisaged here as "one typical event in a series of such performative ritual events, recurring continually in Aegina throughout time." ${ }^{36}$

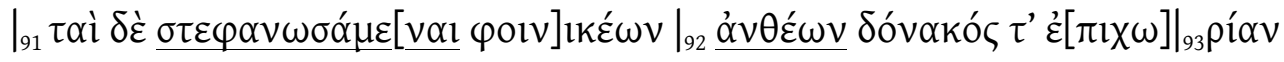

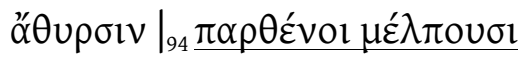

'And the maidens [parthenoi], garlanding themselves [stephanoûsthai] with the local [epikhōrios] delights of crimson blossoms [anthea] and the shepherd's pipe, sing and dance [melpein].'

Bacchylides Ode 13 lines 91-94

Sight fuses with sound here in the vision of maidens singing and dancing together. As I interpret this passage, the delight that comes from hearing the tune of the epichoric or 'local'

156-178). For more on choral performance as a fusion of ritual and myth, with a focus on the Delian Maidens, see Kowalzig 2007:67-68, 71-72, 102 (she makes no reference to Nagy 1996 or to Power 2000).

${ }^{36}$ Power 2000:81. 
donax 'shepherd's pipe' fuses with the delight that comes from seeing the vibrant color of the blossoms plaited into festive garlands, likewise epichoric or 'local', which adorn the beautiful hair of the singing and dancing maidens. ${ }^{37}$ The highlighting of the predominantly crimson color of the garlands traditionally worn by Aeginetan girls at the festive event as pictured here is a special poetic touch that calls attention to the "local color" so typical of epichoric festive events in ancient Greek song culture. ${ }^{38}$

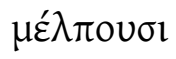

melpein 'sing and dance'

Bacchylides Ode 13 line 94; also later, line 190

The verb melpein here at line 94, as is evident from a survey of its known contexts, refers to both the singing and the dancing of a khoros. ${ }^{39}\{186 \mid 187\}$

This verb must have been followed by a direct object indicating who is being glorified first of all by the group of singing and dancing maidens, but there is a break in the text at this point. The most likely way to restore the missing part of the text is to conjecture that one of the missing words is tekos 'child', referring to the prototypical hero Aiakos as the son of Aegina the prototypical Mother Earth. This glorification of Aiakos is shared with the nymph Aegina, since the break is followed by an invocation of this earth mother.

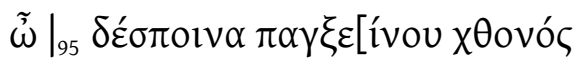

O queen of this land that welcomes all as guests [xenoi]

\footnotetext{
${ }^{37}$ For other examples of donax 'reed' in the sense of 'shepherd's pipe', see Pindar Pythian 12.45; also Homeric Hymn to Pan 15.

${ }^{38}$ More on such "local color" of epichoric garlands in Nagy 2010/2011 II§§416, 419-428.

${ }^{39}$ Nagy 1990a:350-351 (12\$29n62, n64).
} 
This invocation of Aegina highlights her as the earth mother of Aiakos and of the Aiakidai who are his descendants.

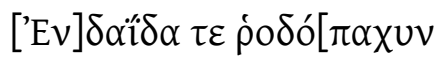
'and Endais, the one with rose-colored arms.'

Bacchylides Ode 13 line 96

After the glorification of Aiakos and of Aegina as the prototypical earth mother of Aiakos and of the rest of the Aiakidai, the next figure to be glorified here is Endais as the wife of Aiakos. She is not only a female prototype of the Aiakidai, second only to Aegina herself. More specifically, she is also the mother of the heroes Peleus (97) and Telamon (98) and thus the grandmother of the heroes Ajax and Achilles (100-104).

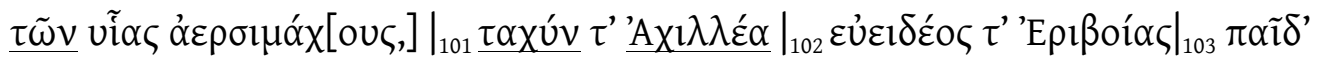

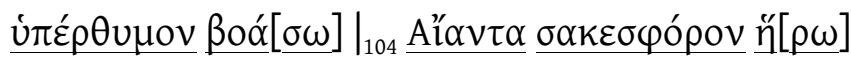

'Stemming from them (Peleus and Telamon) are sons who take upon themselves the burden of battles (and whom I will now name): swift Achilles and then the mighty-spirited son of beautiful Eriboia (the wife of Telamon) will I invoke with a shout [boân], I mean Ajax the shield-bearing hero.' 
I focus here on the performative future declaration that I translate 'I will invoke with a shout [boân]'. ${ }^{\prime 0}$ This ritual shout invokes the names of Achilles and Ajax. Of these two grandsons of Endais and Aiakos, the hero Achilles is invoked first by way of the ritual shout. The shout adorns him with his traditional epithet, 'the swift one'. Next to be invoked is Ajax, adorned with his own traditional epithets: he is 'the mighty-spirited shield-bearing hero'.

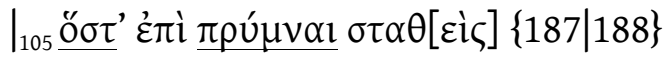

'(Ajax,) the one who, standing on the stern [prumnē] of the ship'

Bacchylides Ode 13 line 105

Immediately after the invocation of Ajax, by way of both his name and his epithets (102104), the victory ode proceeds to conjure an actual vision of the hero: Ajax is visualized standing on the prumne' 'stern' of a ship (105). This visualization has a mythical past in the songmaking traditions of epic, and we will consider this mythical past as it is narrated in the Homeric Iliad.

Before we consider this mythical past in epic, however, it is important to note that this visualization has another mythical past in lyric - that is, in the choral lyric traditions of the victory ode. Even more important, this visualization of a mythical past in the victory ode is matched by a visualization of a ritual present.

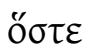

'the one who'

Bacchylides Ode 13 line 105

${ }^{40}$ On this performative future, see Calame 2009:11. 
The ritual present is signaled in Ode 13 by a device conventionally known as a hymnic relative construction. ${ }^{41}$ In this case the hymnic relative pronoun is hoste (ö $\left.\sigma \tau \varepsilon\right)$ at line 105, which I translate as 'the one who', relating to Ajax. In the argumentation that follows this commentary, I will have more to say about such a hymnic relative construction. For the moment, however, I focus on the actual lyric narrative of the mythical past in this victory ode.

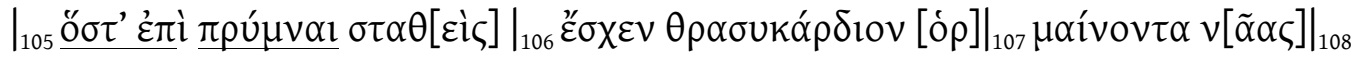

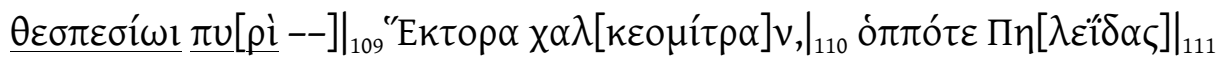

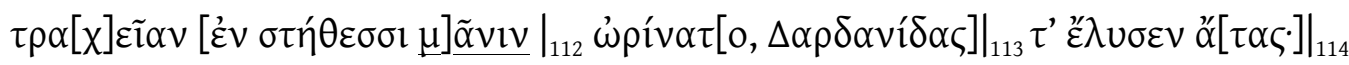

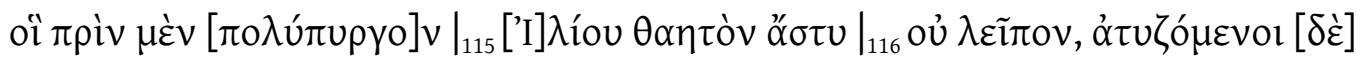

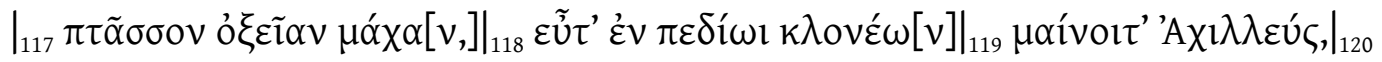

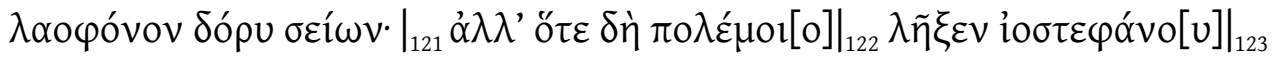

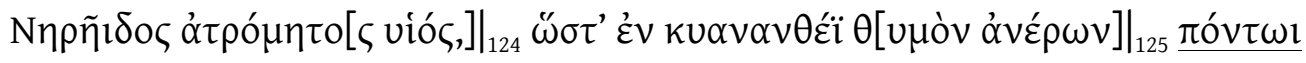

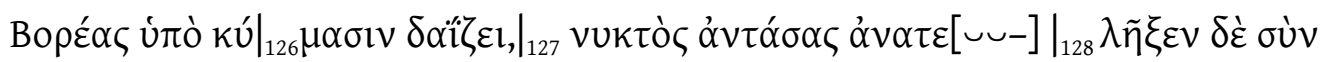

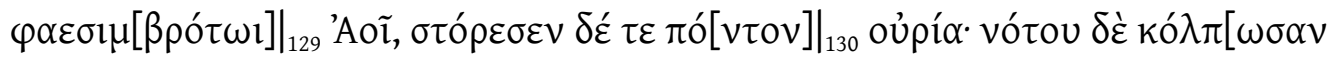

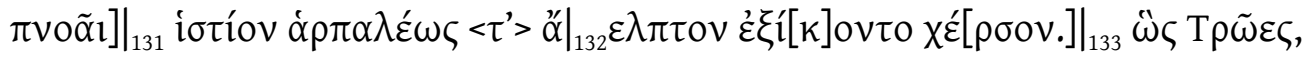

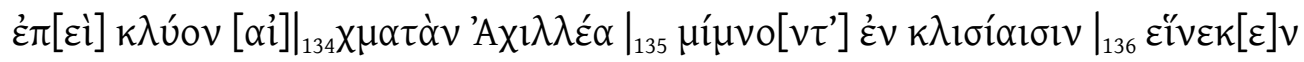

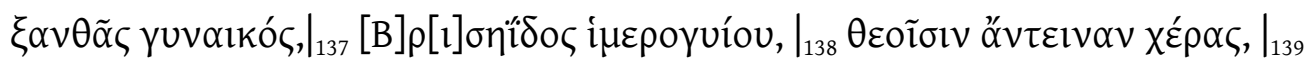

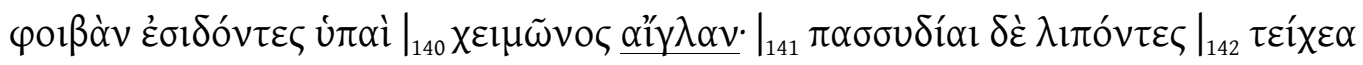

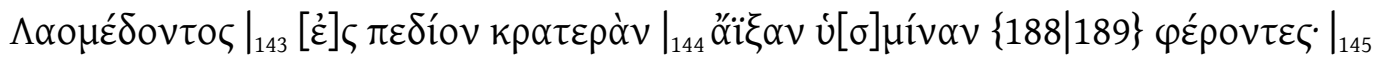

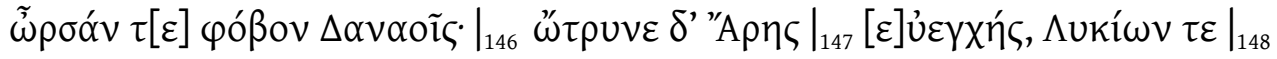

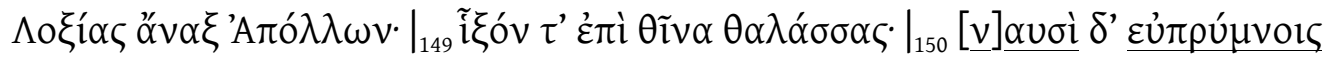

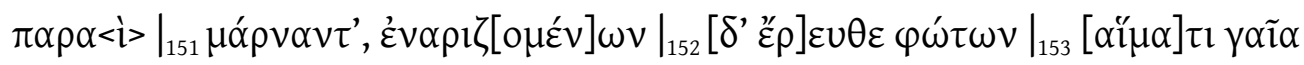

\footnotetext{
${ }^{41}$ On the term hymnic relative, see Calame 2009:10, with reference to ha ( $\left.\ddot{\alpha}\right)$ 'who' at line 97, relating to Endais, and tōn $(\tau \tilde{\omega} v)$ at line 100, relating to Peleus and Telamon.
} 


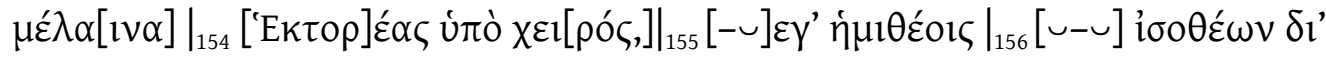

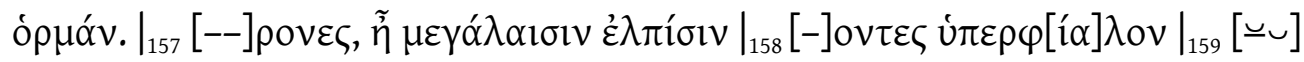

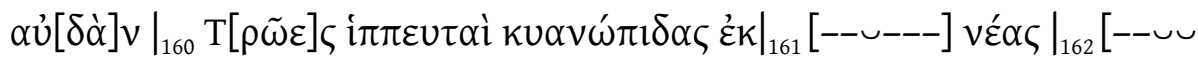

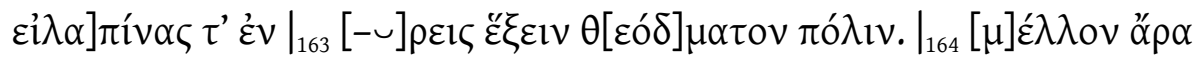

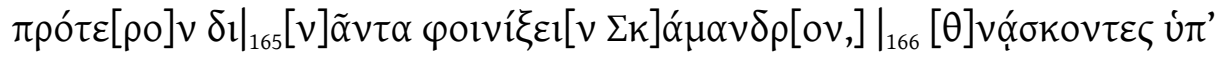
$\left.[A i \alpha] \kappa i ́ \delta \alpha 1 \varsigma\right|_{167} \varepsilon \dot{\varepsilon} \rho \varepsilon ı \psi[1] \pi u ́[\rho \gamma o เ \varsigma] \mid$

(Ajax,) the one who, standing on the stern of the ship, held off Hector of the bold heart. (Hector) was attacking the ships with his fire [pur], wondrous to tell about, [...]. That was when (Achilles) the son of Peleus felt harsh ${ }_{111}$ anger [mēnis] stirring (in his breast) and so it was that he released (the Trojans) from their (pending doom). Earlier, those (Trojans) would never come out from their splendid city of Ilion. They were confounded, trembling in fear of fierce battle whenever Achilles was raging in the (Trojan) Plain, brandishing his man-killing wooden spear. But when the fearless son of the Nereid who wears the violet garland stopped fighting the war - just as Boreas the North Wind, on $\mathrm{a}_{125}$ sea [pontos] blossoming in dark blue, tears away at the spirit of men, beset as they are by the waves, as he comes to face them when night approaches, but he lets up with the coming of Dawn, who brings light to mortals, and a tail wind levels the sea while the sails fill out with the breath of Notos the South Wind, and the men eagerly reach dry land, which they never thought they would see again - so also the Trojans, when they heard that Achilles the spearman was staying in his shelter, all because of that woman with the hair of gold, Briseis, the one with the limbs that arouse desire, lifted up their hands, up toward the gods, seeing the bright ${ }_{140}$ radiance [aiglē] coming out from under the stormy sky. And now, with 
all speed, they left behind the city walls of Laomedon and rushed to the (Trojan) Plain, bringing harsh combat. And they stirred up fear in the Danaoi (Achaeans) and were driven ahead by Ares, the one with the true spear, and by Apollo Loxias, lord of the Lycians. They reached the shore of the sea, and they fought there right next to the ${ }_{150}$ ships, which had true sterns [eu-prumnoi]. And the black earth turned red with all the blood of men being killed by the hand of Hector. [...] for the demigods [hèmitheoi] [...] because of the attack by [...] equal to the gods [isotheoi]. [...] Oh yes, in their great hopes [...] overweening voice [...] the Trojan charioteers [...] ships painted dark blue on each side [...] feasts [...] will possess the city built by the gods. Before any such thing could happen, they would make red the swirling waters of the river Scamander, dying at the hands of the Aiakidai, who make the city towers collapse.

Bacchylides Ode 13 lines 106-167

$\{189 \mid 190\}$ In this remarkable visualization of the mythical past, the Trojans are deluded by the false expectation that they will be saved from destruction.

$[\mu] \tilde{\alpha} v i v$

mēnis 'anger'

Bacchylides Ode 13 line 111

The Trojans expect to be saved from destruction because the mennis 'anger' of Achilles, who is the greatest warrior of the Achaeans, has taken him out of the war with the Trojans. This 
word menis is the driving force of the epic narrative of the Iliad as we know it. ${ }^{42}$ And, as we are about to see, the same word becomes an undercurrent in the lyric narrative of Ode 13.

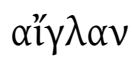

aiglē 'radiance'

Bacchylides Ode 13 line 140

The Trojans' false sense of salvation is signaled in a simile that highlights the aigle 'radiance' (140) marking the cessation of dark skies and stormy winds that sweep over the pontos 'sea' (125). There is a comparable sense of aiglē 'radiance' in the following words of Pindar:

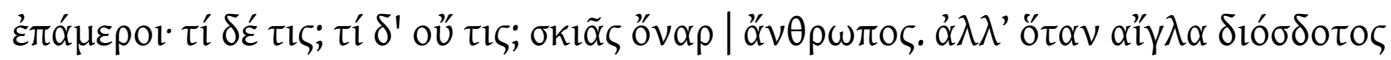

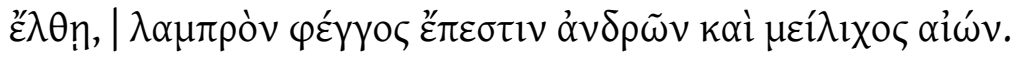

'Creatures of a day. What is a someone, what is a no one? Man is the dream of a shade. But when the radiance [aiglē] that is given by Zeus comes, then there is a light shining over men, and the recircling of time [aiōn] is sweet to the taste.'

Pindar Pythian 8.95-97

Here is what I have written elsewhere about this passage:

In Homeric usage the word skia can designate a dead person. I suggest that the shade of the dead person is literally dreaming - that is, realizing through its dreams - the living person. In other words, the occasion of victory in a mortal's

\footnotetext{
${ }^{42}$ Muellner 1996.
} 
day-to-day lifetime is that singular moment when the dark insubstantiality of an ancestor's shade is translated, through its dreams, into the shining life-force of the victor in full possession of victory, radiant with the brightness of Zeus. It is as if we the living were the realization of the dreams dreamt by our dead ancestors. ${ }^{43}\{190 \mid 191\}$

Earlier, I said I would show that the aigle 'radiance' of Zeus in the context of this passage from Pindar's Pythian 8 is envisioned as a clear sky that follows a spell of fearsome darkness for sailors beset by a storm at sea. In a passage that comes immediately after the passage I just quoted from Pythian 8, we see the emergence of a nautical metaphor for salvation. This metaphor is embedded in a prayer addressed primarily to the earth mother Aegina, calling on her to send the Aiakidai on a naval mission to rescue the Aeginetans in their hour of need:

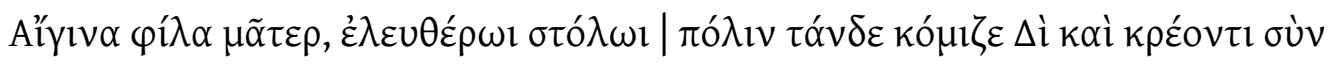

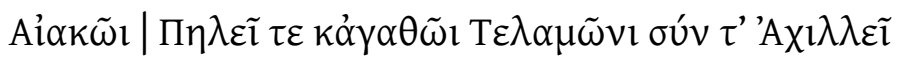

'Aegina! Mother near and dear! Make a (naval) mission [stolos] of freedom for this polis [= the island state of Aegina] as you bring it back to safety, back to Zeus! May it happen with the help of Aiakos the Ruler. And of Peleus. And of noble Telamon. And especially of Achilles.'

Pindar Pythian 8.98-100

In the argumentation that follows this commentary, I will elaborate on the nautical imagery embedded in this passage picturing the Aiakidai as saviors of Aegina.

\footnotetext{
${ }^{43}$ Nagy 1990a:195-196 (6\$88). As I argue in Nagy 2000, this interpretation is not necessarily at odds with other interpretations that stress the presence of another theme in this passage: that human life is sadly ephemeral (for references, see further at Nagy 1990a:195 [6\$88] n211 and n212).
} 
$\pi o ́ v \tau \omega l$

pontos 'sea'

Bacchylides Ode 13 line 125; cf. line 129

This word indicates the setting of the storm sent by Zeus. In the Homeric Iliad as we know it, there are similes referring to the violence of Hector, which threatens to destroy the beached ships of the Achaeans, and comparing this violence to stormy winds (IX 4-7, XI 297-298) that sweep over the pontos 'sea' (IX 4, XI 298). ${ }^{44}$ In the Iliad, however, by contrast with what we see in Ode 13 of Bacchylides, these similes envisioning stormy winds at sea are used to signal a threat of destruction for the Achaeans, not for the Trojans.

$$
\begin{aligned}
& \pi v[\rho i ̀ \\
& \text { pur 'fire' }
\end{aligned}
$$

Bacchylides Ode 13 line 108

As we will now see, the violence of Hector is figured not only as a storm at sea. It is also figured as the pur 'fire' that he brings to set ablaze the beached ships of the Achaeans. But this fire is not a simile for the violence of Hector. It is a direct instrument of this violence. $\{191 \mid 192\}$

In the Homeric Iliad, the character of Hector speaks of this fire as the visual mark of his greatest epic moment, destined to go on permanent record in epic memory:

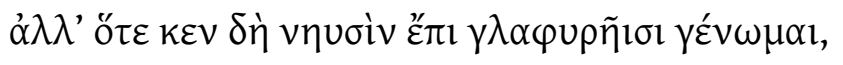

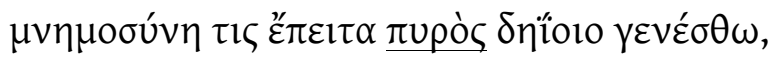

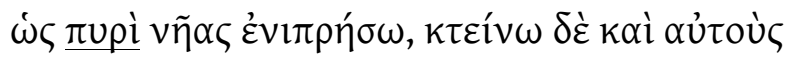

\footnotetext{
${ }^{44}$ Nagy 1979:333-334, 339 (20§§13-15, 20).
} 


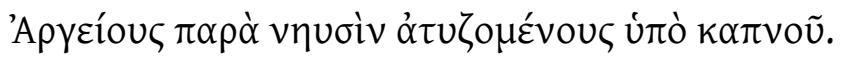

But when I (Hector) get to the hollow ships,

let there be some memory [mnèmosunē] in the future of the burning fire [pur],

how I will set the ships on fire [pur] and kill

the Argives (Achaeans) right next to their ships, confounded as they will be by the smoke.

Iliad VIII 180-183

The fire that Hector foresees here in Iliad VIII will become a visual reality for his enemy Achilles in Iliad XVI. Now Achilles himself will get to see the fire of Hector at the very moment when it finally makes contact with the ships of the Achaeans (XVI 122-124). As I argue in my book Best of the Achaeans, Achilles at this moment sees the ultimate fulfillment of his mēnis 'anger', which is figured as the passive equivalent of the active anger of Zeus when that allpowerful god of lightning inflicts his violent thunderstorms on humankind, especially on sailors at sea. ${ }^{45}$ For Achilles, the moment when Hector sets on fire the ships of the Achaeans (XVI 122-124) signals the end of his wish that the Trojans should reach the ships and the beginning of his concern that these ships should be saved from the fire of Hector (XVI 127128). ${ }^{46}$ So, in terms of the Iliad as we know it, the moment that signals ultimate salvation for the Achaeans is precisely the moment when the destructive fire of Hector finally reaches their ships. And, conversely, that same moment signals ultimate destruction for the Trojans. So also in Ode 13 of Bacchylides, the aigle 'radiance' (140) that comes with the cessation of violent

\footnotetext{
${ }^{45}$ Nagy 1979:335-337 (20\$16).

${ }^{46}$ Nagy 1979:336 (20\$16).
} 
winds signals the ultimate salvation of the Achaeans, not of the Trojans, who are deluded in their expectations.

Unlike the Iliad as we know it, however, Ode 13 of Bacchylides highlights not Achilles but Ajax as the savior of the Achaeans. In Ode 13, when Ajax is pictured as standing on the prumne 'stern' of a ship (105), he is singled out as the Achaean hero who 'held off Hector, the one with the bold heart, who was attacking the ships with his fire [pur], wondrous to tell about' (100$104) .{ }^{47}\{192 \mid 193\}$

Unlike Ode 13, the Iliad as we know it shades over the accomplishment of Ajax at the decisive moment when Hector's fire reaches the ships of the Achaeans. To show this, I offer here a compressed summary of what happens in Iliad XV and XVI.

In Iliad XV, Ajax is pictured as going up to the ikria 'decks' of the beached ships (676), jumping from one deck to another (685-686); undeterred by these defensive actions of Ajax, the attacking Hector takes hold of the prumne 'stern' of one of the ships, the ship that had belonged to the hero Protesilaos (705-706), first of the Achaeans to be killed at Troy, and, holding on to this prumne (716), Hector calls on his fellow Trojans to bring him fire so that he may set this specially prized ship ablaze (718); in this context, Hector describes himself as fighting next to the prumnai 'sterns' (722) of the ships, which had been pulled ashore with their backs facing away from the sea and facing toward the attacking Trojans $(718-725) .{ }^{48}$ At this very moment in the narrative, as Hector makes his decisive move, Ajax is said to be unable to

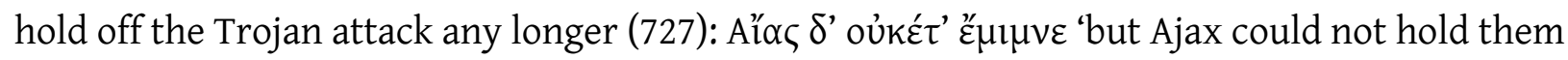
off any longer'. Now Ajax steps back (728) and steps off the ikria 'deck' of the ship of Protesilaos (729), which is where he had been standing (730). So he now fights on a lower level (729) and

\footnotetext{
${ }^{47}$ This detail is emphasized by Fearn 2007:124.

${ }^{48}$ On the Homeric visualization of the Achaean ships beached on the shores of the Hellespont, I refer to my analysis in Nagy 2009/2010 II§71.
} 
from further back inside the ships (728), but at least he continues to fight back (743-746), encouraging his fellow warriors to fight back as well (732), and his words of encouragement, as quoted (733-741), are uttered in the form of a ritual shout, as expressed by the verb boân (732).

In Iliad XVI, the narrative about the situation of Ajax continues (102-124), starting with the

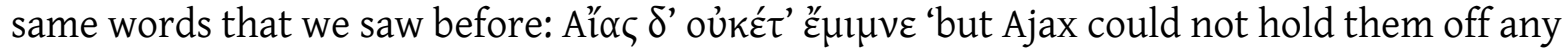
longer' (102). In the course of this continued narrative, Hector with a single stroke of his sword shears off the tip of the ash spear of Ajax (114-121), thus depriving the wooden shaft of its bronze point or aikhme $(115) .^{49}$ This epic moment turns out to be decisive, since Ajax is now forced to withdraw (122). Right then and there, the ship of Protesilaos is set on fire (122-124), and the Homeric narrative comes to a climax with a vision of the flames of Hector's fire enveloping the prumne 'stern' of the ship of Protesilaos (124). This vision is the signal for what happens next in the master narrative of the Iliad. Achilles will now send forth Patroklos to stop the fire that Ajax was unable to stop (124 and following). $\{193 \mid 194\}$

By contrast with Ode 13 of Bacchylides, where Ajax is the hero who holds off Hector and his fiery menace from the ships of the Achaeans, the Iliad highlights Patroklos. In this epic, it is Patroklos who turns back the Trojans and puts out the fire of Hector: $\dot{\varepsilon} \kappa \nu \eta \tilde{\omega} \nu \delta^{\prime} \varepsilon^{\prime} \lambda \alpha \sigma \varepsilon v, \kappa \alpha \tau \grave{\alpha}$

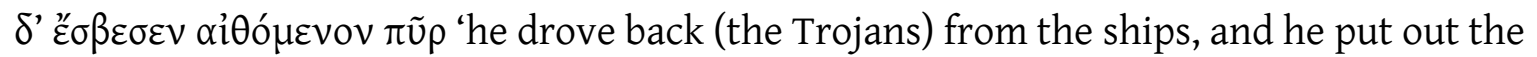
blazing fire' (XVI 293). ${ }^{50}$ And the Iliad actually signals the turning point when the Trojans are driven back: it is the moment when Patroklos kills a Trojan ally by the name of Pur-aikhmēs (Iliad XVI 287). The name of this hero means 'he whose spear point [aikhmē] has fire [pur]..

$$
\left.\right|_{169} \hat{\eta} \beta \alpha \theta u \xi u ́ \lambda \omega[1 \pi v \rho \tilde{\alpha} 1 . . .]
$$

\footnotetext{
${ }^{49}$ On the ritual meaning of the epic moment when Hector shears off the tip of the spear of Ajax, see Smoot 2008.

${ }^{50}$ Commentary by Nagy 1979:336-337 (20\$17).

${ }^{51}$ I owe this perceptive observation to Smoot 2008.
} 
'or on [the pyre] built high with much timber'

The narrative moves ahead and pictures the funeral pyre on which the corpse of a hero will be cremated - perhaps the corpse of Hector. A reference to the fire that is lit in this context may well be linked with the earlier mentions of fire. ${ }^{52}$

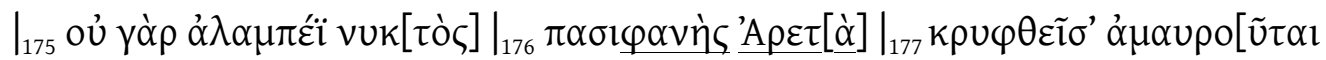

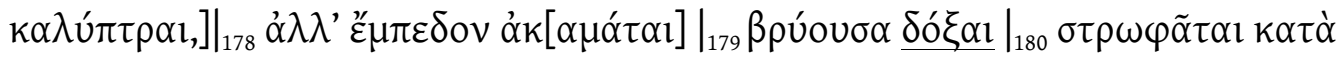

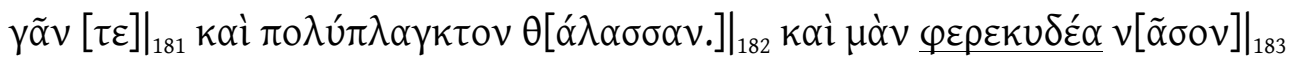

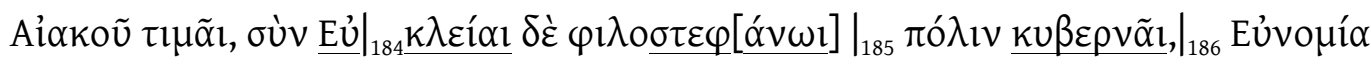

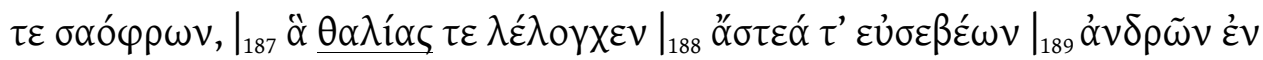

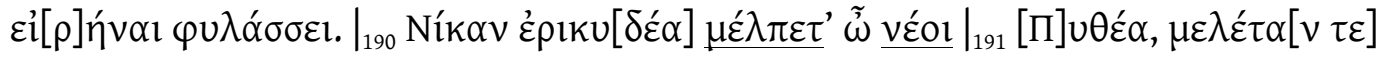

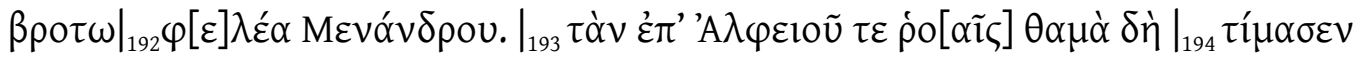

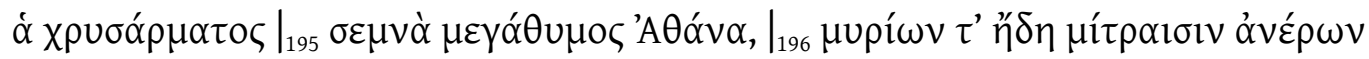

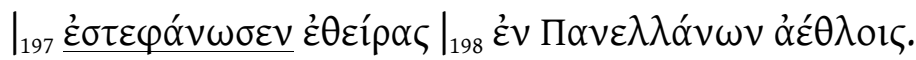

'For the goddess of ${ }_{176}$ achievement [aretē], making herself visible [phainein] to all, is not darkened over by the lightless veil of night. Flourishing forever with $\mathrm{a}_{179}$ fame $[$ doxa $]$ that will not wear out, this goddess ranges over land and also over the sea, that sea which makes men veer off in many ways. Yes, this goddess gives honor to the island of Aiakos, an island ${ }_{182}$ which wins as a prize [phere-] brilliant success [kudos], and, together with the ${ }_{183-4}$ goddess of true glory [kleos], the one who loves garlands [stephanoi], (this goddess of achievement) ${ }_{185}$ steers straight [kubernân] the city. Joining (these goddesses) is the goddess of true rule, the one whose thinking is balanced. She has been put in charge of ${ }_{187}$ festivities

\footnotetext{
${ }^{52}$ Fearn 2007:132.
} 
[thaliai] and she guards in peace the cities of men who are ritually pure. So, ${ }_{190}$ sing and dance [melpein], O young men $\{194 \mid 195\}$ [neoi], the victory of Pytheas, a victory which shows brilliant success [kudos], and (sing and dance) the care given by Menandros, which is ever helpful for mortals. That (care) has been honored time and again near the streams of the river Alpheios by Athena, who has the golden chariot, who is the holy goddess with the mighty spirit, and she has already ${ }_{197}$ garlanded [stephanoûn] with headbands the locks of countless men in the contests of Hellenes assembled all together.'

Bacchylides Ode 13 lines 175-198

The song here envisions a flash of light emanating from the achievement or arete (117) of the victorious athlete, which is personified here as a goddess who makes that achievement visible to all, and this 'making visible' is expressed by the verb phainein (177). This goddess of achievement or aretē is envisioned as 'steering straight' (kubernân 185) the seafaring people of the island state of Aegina. So this state is envisioned here as a ship of state, and that ship is now sailing on a most dangerous sea, a sea 'that makes men veer off in many ways' (181). And this same goddess of achievement or aretē is linked with the fame or doxa (179) of the song that celebrates the victory - and with the true glory or kleos (185) that the song brings to the victor. Such a song of true glory is personified here as a second goddess, fused in song with the first goddess, the one who is achievement or arete personified. This second goddess, who is glory or kleos personified, is linked with garlands or stephanoi (184) plaited with blossoms. And these two goddesses, linked with a fair voyage for the ship of state and with garlands of blossoms for victorious athletes, are in turn fused in song with a third goddess, who is the personification of eunomia - a word I translate as 'true rule'. The political rule of a state is 'true' if it is ritually and morally 'good' - as expressed by eu- 'good, genuine, true' in the compound eu-nomia. This third 
goddess as 'true rule' personified has a special link to the first goddess, whose steering of the ship of state is a metaphor for the kind of political rule that is 'true' because it is ritually and morally 'good'. And, with her attribute of festivities or thaliai (187), this third goddess also has a special link to the second goddess, whose blossoms are a metaphor for the festivities that mark the third goddess, since the noun thalia 'festivity' is actually derived from a verb meaning 'to blossom', which is thallein. ${ }^{53}$ The passage comes to a climax with the garlanding of the victor, as expressed by the verb stephanoûn (197).

$$
\begin{aligned}
& \mu \varepsilon ́ \lambda \pi \varepsilon \tau \text { ' } \\
& \text { melpein 'sing and dance' }
\end{aligned}
$$

Bacchylides Ode 13 line 190; also earlier, line 94

$\{195 \mid 196\}$ In this same context, we find a ritual injunction that calls on the neoi 'young men' (190) to sing and dance the victory that is being celebrated by the victory ode, and the word used to express the combined singing and dancing is melpein (190). This usage mirrors the envisioned performance of the parthenoi 'maidens' (94) who notionally sing and dance the story of the Aiakidai: in that context as well, as we saw earlier in the commentary, the word used to express the combined singing and dancing is melpein (94). This envisioned performance of a female group of singers and dancers, which is figured as a khoros, is embedded within the actual performance of a male group of singers and dancers, which is figured as a komos. So the singing and dancing group of male performers here is making a mimessis of a singing and dancing group of female performers.

\footnotetext{
${ }^{53}$ I note here the useful interpretation of line 187 by Calame 2009:14.
} 
Earlier in the commentary, I noted that the khoros is a medium that makes mimēsis: in other words, the khoros re-enacts in ritual song and dance what happens in myth. Now I note further that the male kōmos that actually performs the singing and dancing of ode 13 of Bacchylides is in turn making a mimessis of the mimēsis made by the female khoros that figuratively performs the singing and dancing. ${ }^{54}$ And such mimessis of the khoros by the kōmos, because it re-enacts in ritual song what happens in myth, augments the authority of the komos and enhances its mimetic power..$^{55}$

I see a comparable mimessis of mimēsis at the closing of Ode 17 of Bacchylides, but here the embedded mimessis is performed not only by a prototypical female khoros but also by a prototypical male khoros: there are matching khoroi 'choruses' here of seven young maidens and seven young men performing respectively a ritual cry of ololugēe ( $\left.\dot{\omega} \lambda{ }^{\prime} \lambda \nu \xi \alpha v 127\right)$ and a paean ( $\pi \alpha 1 \alpha$ vi $\xi \alpha \vee 129)$ to celebrate their liberation by Theseus from the bondage imposed by Minos, king of the Cretan thalassocracy. ${ }^{56}$ Re-enacting these matching male and female $\{196 \mid 197\}$ khoroi here is a unified khoros of singers and dancers who are the actual performers of Ode 17 of Bacchylides.

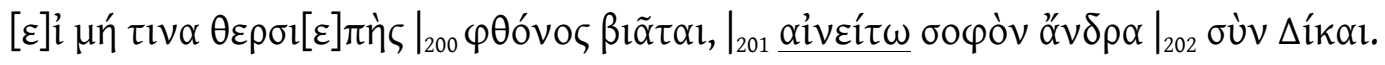

\footnotetext{
${ }^{54}$ Relevant are my comments in Nagy 1996:56-57, where I argue that the Delian Maidens, as envisioned in the Homeric Hymn to Apollo (verses 156-178), are an idealized khoros that is re-enacted, on seasonally recurring occasions, by actual khoroi. See also Kowalzig 2007:102. She argues that the Delian Maidens, as an idealized khoros, could be re-enacted by "male theoric choruses." In making this argument, she points out that "Athenian dramatic khoroi, arguably pivotal in fostering democratic ideology, were consistently composed of men, regardless of the gender of the mythical dancers they represented."

${ }^{55}$ This last formulation has been enhanced by a correspondence I had with Emrys Bell-Schlatter (2010.02.28).

${ }^{56}$ On ololuge 'ululation' as a feature of singing and dancing performed by khoroi of women, see Nagy 2009/2010 II\$290. On Ode 17 of Bacchylides as an expression of ideologies stemming from the political realities of the Delian League of Athens, see Kowalzig 2007:88-94.
} 
'Whoever is not overcome by the envy that comes from speaking outrageously, let him praise [ainein] the one who understands, with the help of the goddess of justice.'

Bacchylides Ode 13 lines 199-202

As I noted earlier on, the song comes to an end here with an injunction to authorize by way of praise, ainein, the one who understands the song (201).

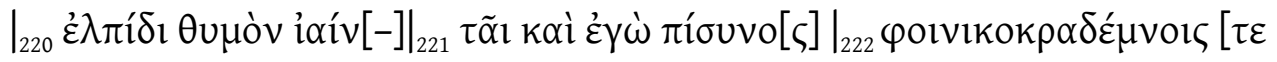

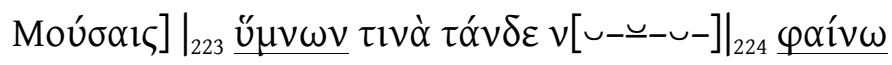

'... fueling the sprit with hope. And I, relying on that hope, and relying on the Muses with their headbands of crimson, ${ }_{224}$ make visible [phainein] this (gift) of songs [humnoi]'.

Bacchylides Ode 13.220-224

The word phainein at line 224, meaning 'make visible', is once again being linked to the power of the song to visualize its own power to visualize. The same word phainein 'make visible', as I have already noted, is used in a comparable sense at line 76 and 83. And what the song has the power to visualize is the song itself, which is expressed here at the end of the song by way of the noun humnos at line 224, meaning 'song'. In an earlier context, as we saw, the blossoms of the garland that is the song are said to illuminate the fame that the song

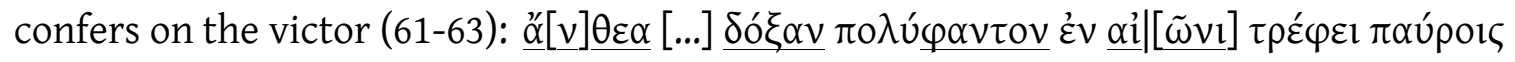
$\beta \rho o \tau \tilde{\omega} v \mid[\alpha]$ izí '... the blossoms [anthea] nurture a fame [doxa] that is polu-phantos (made visible [phainein] to many) in the completion of time [aiōn] - a fame meant for only a few mortals, lasting forever [aiei]'. In this context, the fame that comes with the victory ode is described by 
the adjective polu-phantos 'made visible to many'. This adjective, derived from phainein 'make visible', conveys once again the power of the victory ode to visualize.

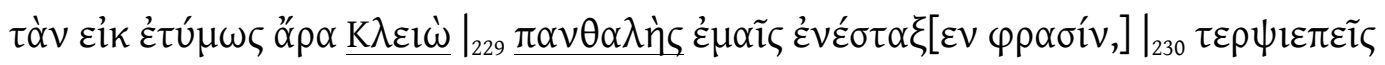

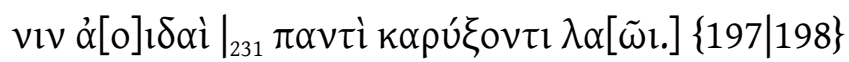

'... if this song was really infused into my thinking by ${ }_{228}$ Kleiō, who is ${ }_{229}$ all-

blossoming [pan-thalēs], then he (who is praised) will be proclaimed to the whole population by songs that bring delight with their words.'

Bacchylides Ode 13.228-231

Here at line 228, near the end of the song, we find a circling back to Kleiō, the Muse who presides over the kleos 'glory' of song: her name was invoked already at line 9, near the start of the song. She is the 'all-blossoming' goddess, the pan-thales, whose blossoms make the garland that is the song.

\section{The argument}

Poetic gestures like the garlanding of the victor in Ode 13 of Bacchylides (197) are evidently metaphors for the primary poetic gesture in a victory ode, which is, the praising of the victor. But such metaphors are not just poetic gestures. They are ritual acts. Even the primary poetic gesture in a victory ode, the praising of the victorious athlete, is a ritual act in its own right. Further, these ritual acts are actually connected with each other - as ritual acts. Even further, such ritual acts as the garlanding of the victor are not only metaphors for the primary ritual act of praising the victor: they are also metonyms of that primary act. 
For a working definition of metonym here, I mean an expression of meaning by way of connection, as opposed to metaphor, by which I mean an expression of meaning by way of substitution. ${ }^{57}$

Relevant to such an understanding of the word metonym is the concept of connectivity, which I invoked a moment ago when I said that the ritual acts of praising a victor and of garlanding the victor are connected with each other as ritual acts. What we see here is a sacral metonymy, which is a poetics of ritual connectivity.

With this concept of ritual connectivity in mind, I argue that all ritual acts that are used as metaphors for the ritual act of praising the victorious athlete in the victory ode are also metonyms. All of these ritual acts are connected with each other in the ritual setting of the actual performance of the victory ode. It is in this context, I must add, that we need to understand hymnic relative constructions, as in the case of the hymnic relative pronoun hoste (ö $\tau \varepsilon$ ) at line 105, meaning 'the one who'. Such relatives are ritual markers of connectivity between the ritual acts and the myths that correspond to them.

To show further the workings of sacral metonymy in Ode 13 of Bacchylides, I start by taking a second look at the end of the ode, where $\{198 \mid 199\}$ the flash of light emanating from the achievement or $\operatorname{aret} \bar{e}(117)$ of the victorious athlete is personified as a goddess Aretē who makes that achievement visible to all, as expressed by the verb phainein (177). This goddess of achievement, as we have seen, is 'steering straight' (kubernân 185) the island state of Aegina, which is thus envisioned as a ship of state. And this same goddess is linked by sacral metonymy with the fame or doxa (179) of the song that celebrates the victory - and with the true glory or kleos (185) that the song brings to the victor. Such a song of 'true glory', as we have also seen, is personified as a second goddess, Eukleia (183-184), who is fused in song with the first goddess,

\footnotetext{
${ }^{57}$ Nagy 2003:ix.
} 
Aretē or 'achievement' personified. This second goddess, who is Eukleia or 'true kleos' personified, is linked by sacral metonymy with stephanoi 'garlands' (184) plaited with blossoms. And the sacral metonymy extends further: these two goddesses, one of whom is linked with a fair voyage for the ship of state while the other is linked with garlands of blossoms for victorious athletes, are in turn fused in song with a third goddess, who is the personification of eunomia, meaning 'true rule'. As we have also seen, this third goddess Eunomia as 'true rule' personified has a special link of her own to the first goddess, whose steering of the ship of state is a metaphor for true rule. And, with her attribute of festivities or thaliai (187), this third goddess also has a special link to the second goddess, whose blossoms are a metaphor for the festivities that mark the third goddess.

In the fusion of these three singing and dancing goddesses, I highlight the linking of the garlands or stephanoi (184) of blossoms with the glory or kleos (183-184) of singing and dancing in the festivities of a victory ode. In terms of my argument, such linking is not just a poetic gesture: rather, the garlanding of the victor, as expressed at the climax of this passage by the verb stephanoûn (197), is also a ritual act, which is part of the overall ritual act of performing the victory ode.

To show further the connectedness of the ritual acts in Ode 13, I propose now to take a second look at the gesture of a ritual shout calling on the names of the heroes Achilles and Ajax:

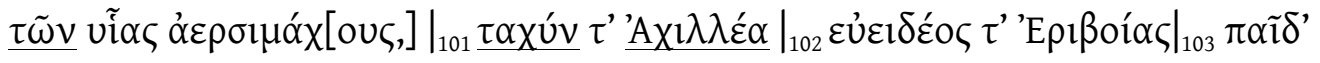

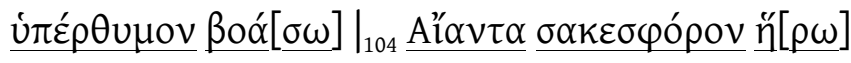

'Stemming from them (Peleus and Telamon) are sons who take upon themselves the burden of battles (and whom I will now name): swift Achilles and then the 
mighty-spirited son of beautiful Eriboia (the wife of Telamon) will I invoke with a shout [boân], I mean Ajax the shield-bearing hero.'

Bacchylides Ode 13 lines 100-104

$\{199 \mid 200\}$ As I pointed out in the commentary, this ritual shout invokes the names of Achilles and Ajax. Of these two grandsons of Endais and Aiakos, the hero Achilles is invoked first by way of the ritual shout. The shout adorns him with his traditional epithet, 'the swift one'. Next to be invoked is Ajax, adorned with his own traditional epithets: he is 'the mighty-spirited shield-bearing hero'.

We may compare such a ritual shouting out of the heroes' names with another ritual shout, signaled in an ode of Pindar, Nemean 5, which celebrates the same athletic victory of Pytheas that is being celebrated here in Ode 13 of Bacchylides. In Pindar's Nemean 5, the festive group of

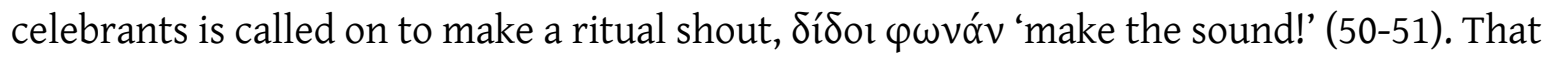

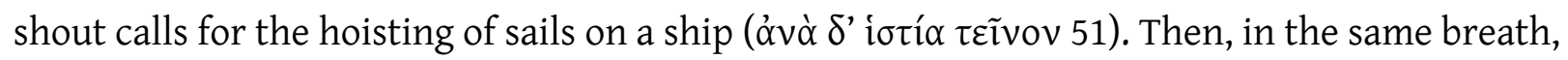
as it were, the group is called on to 'call out' ( $\varphi \theta \varepsilon ́ \gamma \xi \alpha 152)$ the athletic victories of an ancestral predecessor of the athletic victor Pytheas. And then, finally, the group is called on to bring to the entrance of the sacred precinct of Aiakos an offering of garlands: $\pi \rho \circ \theta$ úpololv $\delta$ ' Aỉakov |

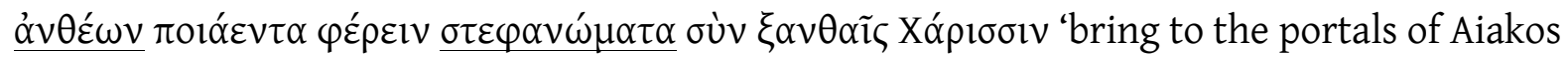
the soft garlandings [stephanōmata] of blossoms [anthea], with the golden-haired Kharites attending' (53-54). And it is on this note that the ode of Pindar comes to a close.

As we saw in the commentary, Ode 13 of Bacchylides comes to a close on a comparable note, with the radiant vision of a garlanded goddess: she is panthalēs 'all-blooming' (229), and she is the Muse of the kleos 'glory' of songmaking, who is none other than Kleiō herself (228).

We just saw a moment ago that Pindar's Nemean 5 makes mention of the sacred precinct of Aiakos, at the entrance to which the festive group of celebrants is called on to bring offerings 
of garlands. The victory ode of Pindar is referring here to the Aiakeion, which was the sacred precinct of Aiakos in his function as the primary cult hero of Aegina. Pausanias gives a detailed description of this sacred precinct, which featured a bōmos 'altar' that supposedly contained the corpse of Aiakos $(2.29 .6-8) \cdot{ }^{58}$ In this connection, I draw attention to the Aiakeia, a seasonally recurring festival celebrated in the environs of the Aiakeion. Pindar's Paean 15 (= S4 ed. Rutherford 2001) was evidently composed for performance on the occasion of this festival of the Aiakeia. ${ }^{59}\{200 \mid 201\}$

As I argue in the article "Asopos and his multiple daughters," the hero cult of Aiakos as manifested in the ritual act of garlanding the entrance to his sacred precinct is relevant to the setting for the actual performance of the victory ode that we know as Pindar's Nemean 5 , in praise of the Aeginetan victor Pytheas. ${ }^{60}$ That is, this ritual act is understood as a part of the performance of the victory ode, which is a ritual act in its own right. Further, I now argue that this hero cult of Aiakos is also relevant to the setting for the actual performance of the victory ode that we know as Ode 13 of Bacchylides. The garlands of this ode, like the garlands of Pindar's Nemean 5, are sacral metonyms. They are part of entire ritual complex that is the victory ode.

And the same can be said about the reference in Ode 13 of Bacchylides to the invoking of

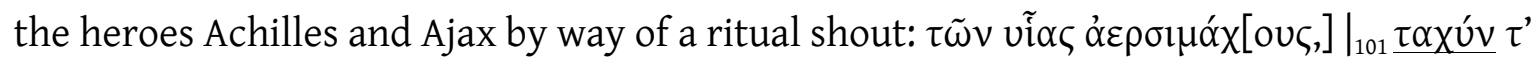

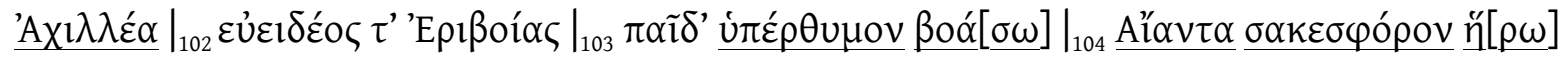
'Stemming from them (Peleus and Telamon) are sons who take upon themselves the burden of battles (and whom I will now name): swift Achilles and then the mighty-spirited son of

\footnotetext{
${ }^{58}$ On the hero cult of Aiakos as worshipped in Aegina, see Fearn 2007:89-90.

${ }^{59}$ See again Fearn 2007:89-90.

${ }^{60}$ Nagy 2010.
} 
beautiful Eriboia (the wife of Telamon) will I invoke with a shout [boân], I mean Ajax the shieldbearing hero' (100-104). This ritual shout is part of entire ritual complex that is the victory ode.

Such a ritual act of invoking heroes can be related to the cults of these heroes. I have in mind here a narrative in Herodotus (8.40-97) where the historian mentions such an invocation. In the article "Asopos and his multiple daughters," I analyze this narrative with reference to the hero cults of Aiakos and of the Aiakidai, including Ajax. ${ }^{61}$ This narrative highlights the role of the hero Aiakos and his descendants, the Aiakidai, as otherworldly helpers of the Hellenes in their struggle against the Persians (Herodotus 8.64 and 8.83-84). Before the naval battle at Salamis, according to this narrative, the combined forces of the defending Hellenes invoked Aiakos and the Aiakidai:

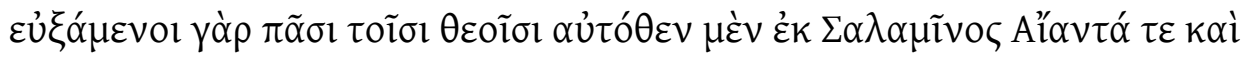

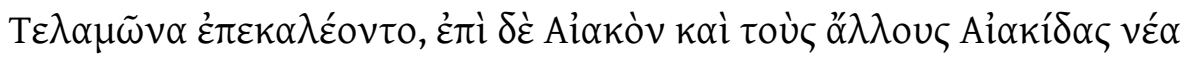

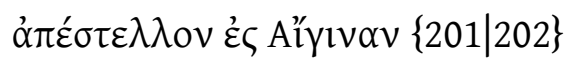

'They prayed to all the gods and then they invoked [epi-kaleîsthai] Ajax and Telamon to come from right there [autothen], from Salamis, but they sent for Aiakos and the other Aiakidai to come (from Aegina), sending on a (naval) mission [apo-stellein] a ship to Aegina.'

Herodotus 8.64.2

When the ship bringing 'Aiakos and the other Aiakidai' from Aegina to Salamis finally arrived at Salamis, it figured most prominently in the successful naval battle there - according to the Aeginetans but not according to the Athenians (Herodotus 8.84.2). In one of Pindar's Aeginetan

\footnotetext{
${ }^{61}$ Nagy 2010.
} 
odes, Isthmian 5 (48), there is an overt reference to the military success of the Aeginetan fleet at the naval battle of Salamis. ${ }^{62}$

In that same article, I concentrate on the use of the verb apo-stellein 'send on a (naval) mission', arguing that it corresponds to the use of the noun stolos '(naval) mission' in Pindar's Pythian 8, composed somewhere around $446 \mathrm{BCE}$. By now the glory days of Aeginetan maritime power were a thing of the past, since Aegina had been subjugated by Athens in $457 \mathrm{BCE} .{ }^{63}$ Still, we find in Pythian 8 a clear evocation of those glory days, in the context of recalling the success of the Aeginetans at the naval battle of Salamis in 480 BCE . Embedded in the ode by Pindar, as we have already seen, is a prayer addressed to the earth mother Aegina, calling on her to send the Aiakidai on a new naval mission:

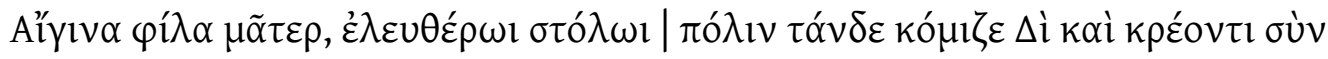

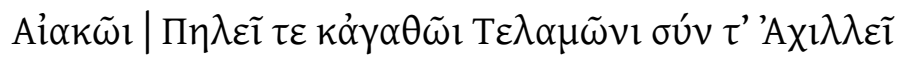

‘Aegina! Mother near and dear! Make a (naval) mission [stolos] of freedom for this polis [= the island state of Aegina] as you bring it back to safety, back to Zeus! May it happen with the help of Aiakos the Ruler. And of Peleus. And of noble Telamon. And especially of Achilles.'

Pindar Pythian 8.98-100

Next I turn to the verb epi-kaleîsthai 'invoke' in the narrative of Herodotus with reference to the ritual invocation of Aiakos and the Aiakidai before the naval battle of Salamis. Let us examine again the context:

\footnotetext{
${ }^{62}$ Nagy 2010.

${ }^{63}$ On the relevance of the subjugation of Aegina by Athens in 457 BCE, see Fearn 2007:91.
} 


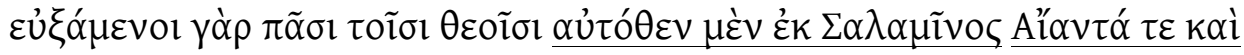

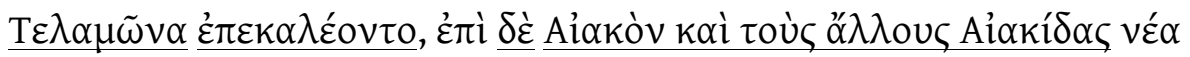

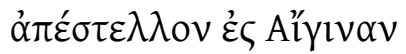

'They prayed to all the gods and then they invoked [epi-kaleîsthai] Ajax and Telamon to come from right there [autothen], on the one hand [men], from Salamis, but, on the other hand [de], they sent for Aiakos and the other Aiakidai to $\{202 \mid 203\}$ come (from Aegina), sending on a (naval) mission [apo-stellein] a ship to Aegina.'

Herodotus 8.64.2

Earlier in the narrative, where the decision to make this ritual invocation is indicated, it is made explicit that the heroes are invoked to help the Hellenes by becoming their summakhoi 'fellow fighters':

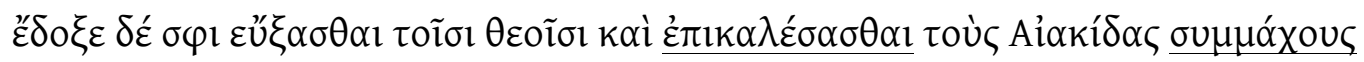

'It was agreed that they would pray to the gods and invoke the Aiakidai as fellow fighters [summakhoi].'

Herodotus 8.64.1

So the question is, which of the Aiakidai are meant here as the summakhoi 'fellow fighters' who will manifest their talismanic power as cult heroes by intervening in the lives of mortals in the here and now? The narrative of Herodotus makes explicit reference to Ajax and Telamon as Aiakidai, and it is relevant to note that the hero cults of these two figures in Salamis were linked with Athenian traditions ever since Salamis had come under the power of Athens in the sixth century BCE. And we know that the Athenians tried to appropriate not only 
Ajax and Telamon as their own native sons. They claimed even Aiakos, creating a sacred precinct for the cult of this hero that rivaled the Aiakeion, which was the sacred precinct of Aiakos in Aegina. ${ }^{64}$ This Athenian appropriation of the cult hero Aiakos himself must be related to the fact that Miltiades and Kimon, as members of the important Athenian patriliny of the Philaidai, claimed to be descended from Aiakos by way of Telamon by way of Ajax (Pausanias 2.29.4; scholia for Pindar Nemean 2.19). Such a notional derivation of an important Athenian patriliny like the Philaidai from the Aiakidai is directly comparable to the notional derivation of important Aeginetan patrilinies like the Psalykhiadai from these same Aiakidai.

According to Aeginetan tradition, by contrast with the rival Athenian claims, Ajax and Telamon were native sons of Aegina, and I argue that the narrative of Herodotus shows traces of such an alternative tradition. When the Aeginetan ship is sent from Salamis to Aegina in order to bring Aiakos and 'the other Aiakidai' from there to Salamis, what is being said by implication is that the ship will bring 'the other Aiakidai' who are actually the native sons of Aegina. For the Aeginetans, 'the other Aiakidai' are their very own Aiakidai, including their very own Ajax and their very own Telamon, and these Aeginetan Aiakidai, once they are brought to the scene of the naval battle, may now be properly $\{203 \mid 204\}$ invoked as summakhoi 'fellow fighters' just as Ajax and Telamon as alternative Aiakidai from Salamis had already been

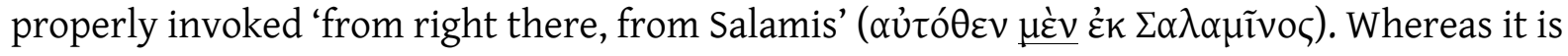
made explicit in the narrative of Herodotus that the Aiakidai of Salamis have already been invoked, 'on the one hand' ( $\mu \varepsilon ́ v)$, it is kept implicit that Aiakos and 'the other Aiakidai', on the other hand $(\delta \dot{\varepsilon})$, will be invoked at Salamis only after the Aeginetan ship brings them from Aegina.

\footnotetext{
${ }^{64}$ The documentation for this Athenian Aiakeion is presented in Fearn 2007:92-93.
} 
We have already seen in a victory ode a reference to such a ritualized naval mission that brings Aiakos and the Aiakidai to the rescue of the Aeginetans. In Pindar's Pythian 8, Aegina as earth mother of Aiakos and of the Aiakidai is invoked in a prayer that calls for such a naval mission, bringing Aiakos, Peleus, Telamon, and Achilles to the rescue of the Aeginetans (98100).

I note here the troubling omission of Ajax from this naval mission. I think it may have to do with an eventual recognition, especially after the subjugation of Aegina by Athens in $457 \mathrm{BCE}$, that this hero, more than any other hero in the lineage of Aiakos and the Aiakidai, had by now been completely appropriated by the Athenians and could therefore no longer be claimed as a native son of the Aeginetans.

There is a reference to another such naval mission in Pindar's Nemean 5, a much earlier ode celebrating an athletic victory that predates by about five years the naval battle of Salamis. As we already saw in that ode of Pindar, the performing group of singers and dancers is called on

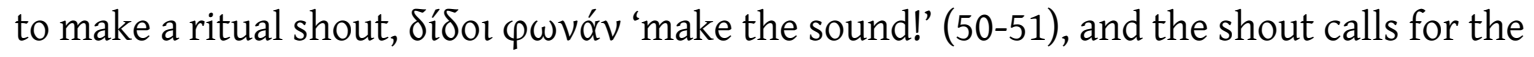

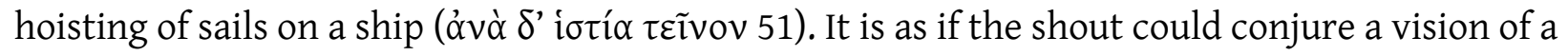
ship that brings the Aiakidai. And the shout that calls for the hoisting of the sails of this ship leads to another shout: in the same breath, as I described it earlier, the performing group is

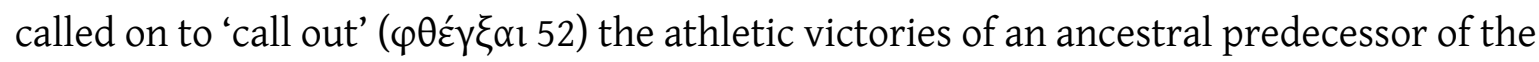
athletic victor Pytheas. We see here a metonymy - a sequence of ritual acts that all connect with each other in the overall ritual frame of the victory ode.

And the metonymy of Pindar's Nemean 5 extends even further. I have already noted what happens immediately after this ritual shout to hoist the sails and praise the victor: at that point, the group of singers and dancers is called on to bring to the entrance of the sacred precinct of Aiakos an offering of garlands: 


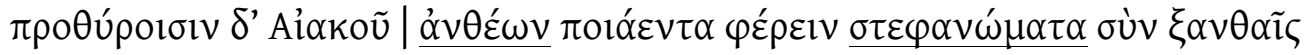
Xóploøiv $\{204 \mid 205\}$

'Bring to the portals of Aiakos the soft garlandings [stephanōmata] of blossoms [anthea], with the golden-haired Kharites attending.'

Pindar Nemean 5.53-54

When I say that the group of singers and dancers is called on to perform a ritual act, including the ritual act of shouting a ritual cry, it must be understood that the act of calling out to call on the group is itself a ritual act, a ritual cry. And this ritual cry that calls on the group comes not from outside the group that sings and dances the victory ode. Rather, this ritual cry comes from inside the group. Whatever is being said or shouted or sung to the group is being performed by the group, in the group. And, like everything else that is being performed in the group, the performance of a ritual cry is a ritual act in its own right.

With this thought in mind, I round out my analysis of the ritual cry in the victory ode by returning one last time to the reference in Ode 13 of Bacchylides to the invoking of the heroes Achilles and Ajax by way of a shout:

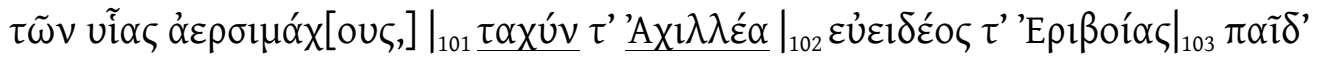

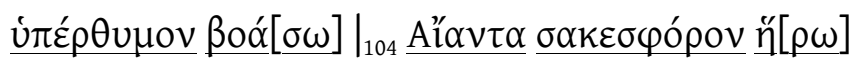

'Stemming from them (Peleus and Telamon) are sons who take upon themselves the burden of battles (and whom I will now name): swift Achilles and then the mighty-spirited son of beautiful Eriboia (the wife of Telamon) will I invoke with a shout [boân], I mean Ajax the shield-bearing hero.' 
I argue that this ritual shout invoking the heroes' names actually conjures a vision of the heroes themselves - a veritable epiphany. And this epiphany of the Aiakidai, just like the shout that conjures the epiphany, is actually being performed by the group who sings and dances the victory ode. Such performance is a ritual act of re-enactment, which is the essence of mimessis.

In other words, I argue that the group of young men who sing and dance Ode 13 of Bacchylides are thereby re-enacting the Aiakidai of the heroic age. Further, as I argue in the article "Asopos and his multiple daughters," there was a comparable re-enactment of the Aiakidai at the naval battle of Salamis as narrated by Herodotus (8.64 and 8.83-84).

In this context, I offer a typological parallel, that is, a historically unrelated but nevertheless instructive point of comparison. I compare the haka traditions of the Maori. In these traditions, participants perform $\{205 \mid 206\}$ ritual shouts and ritual dance poses while standing in war canoes, thus re-enacting their heroic warrior ancestors. ${ }^{65}$

Similarly, I argue, the Aiakidai who figured in Aeginetan ritual events in the fifth century BCE were re-enacting the Aiakidai who figured in Aeginetan mythical events glorified in song and poetry. And a most eminent figure among these Aeginetan Aiakidai would be the hero Ajax himself, pictured as taking his stand on the stern of an Aeginetan ship as he wards off enemies from present and past alike.

On the occasion of the naval battle that was fought at Salamis in $480 \mathrm{BCE}$, the hero Ajax may have been re-enacted by one of his notional descendants, that is, by one of the Aeginetan Aiakidai, in the heroic pose of standing on the stern of an Aeginetan ship that sails on a rescue mission to help his fellow fighters in their hour of need, just as Ajax had stood on the stern of the beached ship of Protesilaos at Troy, warding off the fire of Hector. Earlier, on the occasion of the victory ode that was celebrated at Aegina in $485 \mathrm{BCE}$, which we know as Ode 13 of

\footnotetext{
${ }^{65}$ At the conference to which I refer in the first footnote, I showed a selection of filmed haka re-enactments.
} 
Bacchylides, the hero Ajax may have been likewise re-enacted. In this victory ode, through the mimetic medium of choral song and dance, Ajax was envisioned as standing on the stern of the beached ship of Protesilaos at Troy. But he could also be envisioned as standing on the stern of an Aeginetan ship that sails on some rescue mission at some other moment in the glorious maritime past of the city-state of Aegina. Such other moments are not far from view in Ode 13 of Bacchylides. As we have already seen, this victory ode envisions 'the goddess of achievement [aretē], making herself visible [phainein] to all' (175-176) and 'steering straight [kubernân]' (185) the seafaring people of the city-state of Aegina toward their glorious maritime destiny.

\section{Bibliography}

Bundy, E. L. 1986. Studia Pindarica. Berkeley.

Calame, C. 2007. "Mythos, musische Leistung und Ritual am Beispiel der melischen Dichtung." Literatur und Religion I. Wege zu einer mythisch-rituellen Poetik bei den Griechen (ed. A. Bierl, R. Lämmle, K. Wesselmann; Basiliensia - MythosEikonPoiesis, vol. 1.1) 179-210. Berlin / New York.

Calame, C. 2009. "Referential Fiction and Poetic Ritual: Towards a Pragmatics of Myth (Sappho 17 and Bacchylides 13)." Trends in Classics 1:1-17.

Currie, B. 2005. Pindar and the Cult of Heroes. Oxford.

Fearn, D. 2003. "Mapping Phleious: Politics and myth-making in Bacchylides 9." Classical Quarterly 3:347-367.

Fearn, D. 2007. Bacchylides: Politics, Performance, Poetic Tradition. Oxford.

Fearn, D., ed. 2011. Aegina: Contexts for Choral Lyric Poetry. Myth, History, and Identity in the Fifth Century BC. Oxford. 
Figueira, T. J. 1981. Aegina, society and politics. New York.

Figueira, T. J. 1985a. “The Theognidea and Megarian Society.” Theognis of Megara: Poetry and the Polis (ed. T. J. Figueira and G. Nagy) 112-158. Baltimore.

Figueira, T. J. 1985b. "Chronological Table: Archaic Megara, 800-500 B.C." Theognis of Megara: Poetry and the Polis (ed. T. J. Figueira and G. Nagy) 261-303. Baltimore.

Figueira, T. J. 1991. Athens and Aigina in the age of imperial colonization. Baltimore.

Figueira, T. J. 1993. Excursions in epichoric history: Aeginetan essays. Lanham MD.

Kowalzig, B. 2007. Singing for the gods: Performances of myth and ritual in archaic and classical Greece. Oxford.

Larson, J. 2001. Greek Nymphs: Myth, Cult, Lore. Oxford.

Maehler, H. 1982. ed. Die Lieder des Bakchylides I. Die Siegeslieder II. Kommentar. Leiden.

Muellner, L. 1996. The Anger of Achilles: Mênis in Greek Epic. Ithaca NY.

Nagy, G. 1979. The Best of the Achaeans: Concepts of the Hero in Archaic Greek Poetry. 2nd ed., with new Introduction, 1999. Baltimore.

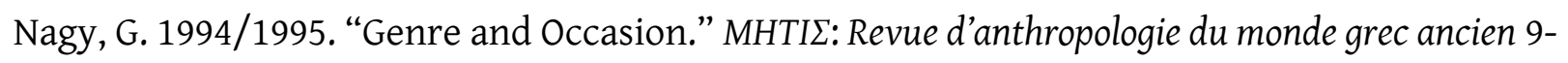
10:11-25.

Nagy, G. 1990a. Pindar's Homer: The Lyric Possession of an Epic Past. Baltimore.

Nagy, G. 1990b. Greek Mythology and Poetics. Ithaca NY.

Nagy, G. 2000. "Dream of a Shade": Refractions of Epic Vision in Pindar's Pythian 8 and Aeschylus' Seven against Thebes. Harvard Studies in Classical Philology 100:97-118.

Nagy, G. 2003. Homeric Responses. Austin TX. 
Nagy, G. 2005a. “The Epic Hero.” A Companion to Ancient Epic (ed. J. M. Foley) 71-89. Oxford.

Nagy, G. 2005b. "The Epic Hero.”

http://chs.harvard.edu/publications.sec/online_print_books.ssp/gregory_nagy_the_epi c/bn_u_tei.xml_5

Nagy, G. 2007a. “Did Sappho and Alcaeus ever meet?" Literatur und Religion I. Wege zu einer mythisch-rituellen Poetik bei den Griechen (ed. A. Bierl, R. Lämmle, and K. Wesselmann; Basiliensia - MythosEikonPoiesis, vol. 1.1) 211-269. Berlin / New York. Second edition 2009 online at chs.harvard.edu.

Nagy, G. 2007b. "Lyric and Greek Myth.” The Cambridge Companion to Greek Mythology (ed. R. D. Woodard) 19-51. Cambridge.

Nagy, G. 2008/2009. Homer the Classic. Cambridge MA and Washington DC. The 2008 online version is available at chs.harvard.edu. The 2009 printed version is distributed by Harvard University Press.

Nagy, G. 2009/2010. Homer the Preclassic. Berkeley / Los Angeles CA. The 2009 online version is available at chs.harvard.edu. The 2010 printed version is published by the University of California Press.

Nagy, G. 2011. “Asopos and his multiple daughters: Traces of preclassical epic in the Aeginetan Odes of Pindar." In Fearn 2011:41-78.

Power, T. 2000. “The Parthenoi of Bacchylides 13." Harvard Studies in Classical Philology 100:67-81.

Rutherford, I. C. 2001. Pindar's Paeans: A Reading of the Fragments with a Survey of the Genre. Oxford. 
Smoot, G. 2008. "The Mitoses of Achilles." First Drafts (see under "Publications" in chs.harvard.edu). 